\title{
REPRODUCTIVE ECOLOGY OF MANGROVE FLORA: CONSERVATION AND MANAGEMENT
}

Jacob Solomon RAJU ALURI *

* Department of Environmental Sciences, Andhra University, Visakhapatnam 530003, India, ajsraju@yahoo.com

DOI: 10.2478/trser-2013-0026

KEYWORDS: mangroves, vivipary, crypto-vivipary, reproductive ecology, conservation, management.

\section{ABSTRACT}

Mangroves are dynamic and unique inter-tidal ecosystems, common in tropical and subtropical coastal environments. They are among the world's most productive ecosystems and are important in protecting coasts from erosion by fierce tides, in promoting the diversity of marine organisms and fisheries by contributing a quantity of food and providing favourable habitats for animals. These economic uses of mangroves indicate that they play an important role in the lives and economies in the coastal regions of different countries. Mangrove forests are under immense threat worldwide due to their multiple economic uses and alterations of freshwater inflows by various upstream activities in catchment areas. Mangrove plants with unique adaptations play a crucial role in sustaining life in mangrove forests. Their reproductive biology is central to understanding the structural and functional components of mangrove forests.

The success of sexual reproduction and subsequent population expansion in mangrove plants is linked to flowering timings, pollinators and tidal currents. Viviparous and cryptoviviparous plants are true mangroves while non-viviparous ones are mangrove associates. The dispersal propagule is seedling in viviparous and non-viviparous plants while it is seed in nonviviparous plants. In this study, viviparous and crypto-viviparous species were included for study. These species are self-compatible, self-pollinating and also cross-pollinating; such a breeding system is a requirement for the success of sexual reproduction and subsequent build up and expansion of population. They are entomophilous in the study region. The viviparous plants include Ceriops tagal, C. decandra, Rhizophora apiculata, R. mucronata, Bruguiera gymnorrhiza and B. cylindrica. The non-viviparous plants include Avicennia alba, A. marina, A. officinalis, Aegiceras corniculatum and Aegialitis rotundifolia. Sexual reproduction and regeneration events are annual in these plants and are dependent on local insects, tidal currents and nutrient content in estuarine environment.

In recent times, erratic and insufficient rainfall together with industrial pollutants released into rivers is causing negative effects on the growth, development and regeneration of mangrove flora. In effect, there is a gradual decrease in mangrove cover. Added to this is continuous exploitation of mangrove plants for fuel wood, creation of shelters for cattle and changes for industrial establishments and aquaculture development in estuarine regions. As a consequence, the existing mangrove cover is struggling to survive and also not in a position to support local needs and provide livelihood opportunities through fishery resources. Further, reduced mangrove cover is showing catastrophic effects on fishing communities who live along the shore line during the period of cyclonic surges and tsunami events. 
ZUSAMMENFASSUNG: Vermehrungsökologie der Mangrovenflora: Erhaltung und Management.

Mangroven sind dynamische und einzigartige Gezeiten-Ökosysteme, die in tropischen und subtropischen Küsten-Gebieten häufig vorkommen. Sie gehören zu den weltweit produktivsten Ökosystemen und sind durch ihren fördernden Anteil an der Vielfalt der marinen Organismen und der Fischerei, durch ihren mengenmäßigen Beitrag an Nahrung sowie die Bereitstellung günstiger Lebensräume für Tiere, von Bedeutung für den Schutz der Küsten vor Erosion während heftiger Gezeiten. Diese wirtschaftlich bedeutenden Nutzungen der Mangroven weisen darauf hin, dass sie im Leben und der Wirtschaft der Küstenregionen vieler Länder eine wichtige Rolle spielen. Mangrovenwälder sind ihrer vielfältigen wirtschaftlichen Nutzungen wegen sowie ihre Veränderungen durch Süßwasserzufuhr infolge verschiedener Tätigkeiten im Einzugsgebiet weltweit hochgradig gefährdet. Die Mangroven Pflanzen mit ihren einzigartigen Anpassungen spielen eine herausragende Rolle in der Erhaltung des Lebens der Mangrovenwälder. Ihre Reproduktionsbiologie ist von zentraler Bedeutung für das Verständnis der strukturellen und funktionellen Komponenten von Mangrovenwäldern.

Der Erfolg der sexuellen Vermehrung und die darauffolgende Ausbreitung der Populationen von Mangroven-Pflanzen führt zur zeitlichen Verknüpfung von Blüte, Bestäuber und Gezeitenströmungen. Lebendgebährende und versteckt-lebendgebährende Pflanzen sind echte Mangrovenarten während nicht lebendgebährende Arten den Magrovenpflanzen beigesellt sind. Die Verbreitungseinheit sind die Keimlinge bei lebendgebährenden und nichtlebendgebährenden Arten, da es ein Same in nicht lebendgebährenden Pflanzen ist. In diese Studie wurden lebengebährende und Krypto-lebendgebährende Arten einbezogen. Diese Arten sind selbst-kompatibel, Selbstbestäuber und auch Fremdbestäuber; ein solches Aufzucht System ist eine Voraussetzung für den Erfolg der sexuellen Fortpflanzung sowie den anschließenden Aufbau und die Ausbreitung der Population. Im Untersuchungsgebiet sind sie entomophil. Die lebendgebährenden Arten umfassen Ceriops tagal, C. decandra, Rhizophora apiculata, $R$. mucronata, Bruguiera gymnorrhiza und $B$. cylindrica. Zu den nichtlebendgebährenden Arten gehören Avicennia alba, A. marina, A. officinalis, Aegiceras corniculatum und Aegialitis rotundifolia. Sexuelle Fortpflanzung und Regeneration gehören zu den jährlichen Ereignissen in diesen Pflanzen und sind abhängig von vorort lebenden Insekten, Gezeitenströmungen sowie Nährstoffgehalt im Bereich der Ästuare.

In der letzten Zeit, haben unregelmäßige und unzureichende Regenfälle zusammen mit Einleitung von industriellen Schadstoffen Wachstum, Entwicklung und Regeneration der Mangrovenflora negativ beeinflusst. In der Tat ist ein allmählicher Rückgang der Mangrovenflächen festzustellen. Hinzu kommt eine kontinuierliche Nutzung der Mangroven für Brennholz, Bau von Unterkünften für Rinder sowie Flächeninanspruchnahme für Industriebetriebe und Entwicklung der Aquakultur in Flussmündungsgebieten. Als Folge hat die vorhandene Mangrovenfläche Schwierigkeiten zu überleben und ist auch nicht in der Lage, lokale Bedürfnisse zu unterstützen und die Möglichkeit für die Bereitstellung einer Existenzgrundlage durch Fischbestände sicher zu stellen. Ferner haben die reduzierten Mangrovenbestände katastrophale Auswirkungen auf die entlang der Küstelinie vom Fischfang lebenden Gemeinden, während Wirbelsturmbrandungen und Tsunami Ereignissen. 
REZUMAT: Ecologia reproductivă a florei de mangrove: conservare şi management.

Mangrovele sunt ecosisteme dinamice şi unice de maree, comune în zonele tropicale și subtropicale de coastă. Acestea sunt printre cele mai productive ecosisteme din lume și sunt importante în protejarea coastelor împotriva eroziunii în caz de maree excepţionale, în promovarea diversității de organisme marine și a pescuitului, a punerii la dispoziţie a unei cantități de produse alimentare și a furnizării de habitate favorabile pentru animale. Aceste utilizări economice ale mangrovelor indică faptul că acestea joacă un rol important în viața și în economiile din regiunile de coastă din diferite țări. Pădurile de mangrove sunt în mare pericol la nivel mondial, datorită multiplelor utilizări economice şi a modificărilor cauzate de intrări de apă dulce în urma unor activităţi din amonte, în bazinul râurilor. Plantele de mangrove, cu adaptări unice, joacă un rol esențial în susținerea vieții în pădurile de mangrove. Biologia lor de reproducere este esențială pentru înțelegerea componentelor structurale și funcționale ale pădurilor de mangrove.

Succesul de reproducere sexuală și extinderea ulterioară a populației de mangrove este legat de perioadele de înflorire, de polenizatori și de curenții mareelor. Plantele vivipare și cripto-vivipare sunt mangrove adevărate, iar cele non-vivipare sunt specii asociate de mangrove. Dispersarea propagulelor se face prin răsaduri la plantele vivipare și non-vivipare și totodată acesta reprezintă sămânţa pentru plantele non-vivipare. În prezenta lucrare au fost incluse specii vivipare și cripto-vivipare. Aceste specii sunt auto-compatibile, autopolenizatoare și, de asemenea, polenizate de alte specii. Un astfel de sistem de reproducere este o cerință pentru succesul reproducerii sexuate şi ulterior pentru dezvoltarea şi extinderea populației. Ele sunt entomofile în regiunea de studiu. Plantele vivipare includ speciile Ceriops tagal, C. decandra, Rhizophora apiculata, R. mucronata, Bruguiera gymnorrhiza și $B$. cylindrica. Plantele non-vivipare includ Avicennia alba, A. marina, A. officinalis, Aegiceras corniculatum și Aegialitis rotundifolia. Reproducerea sexuată și procesele de regenerare sunt anuale la aceste plante și sunt dependente de insecte locale, curenții mareelor și conținutul de nutrienți în mediul de estuar.

În ultima vreme, ploile neregulate şi insuficiente, împreună cu poluanţii industriali eliberaţi în râuri, au influenţe negative asupra creșterii, dezvoltării și regenerării mangrovelor. Într-adevăr, există o scădere treptată a acoperirii cu mangrove. La aceasta se adaugă exploatarea continuă de plante de mangrove pentru lemn de foc, crearea de adăposturi pentru vite și schimbări în vederea amplasării de unități industriale și dezvoltarea acvaculturii în regiunile estuarine. Ca urmare, suprafaţa acoperită de mangrove prezintă dificultăţi de supraviețuire și, de asemenea, nu este capabilă să satisfacă nevoile locale și să ofere oportunități de trai prin intermediul resurselor de pescuit. Mai mult, suprafaţa redusă de mangrove are efecte catastrofale asupra comunităților de pescari care locuiesc de-a lungul liniei țărmului, în perioada ciclonică și a evenimentelor de tsunami.

\section{INTRODUCTION}

Mangrove plants are the key constituents and play a crucial role in sustaining life in mangrove forests. They display special adaptations in root system, shoot system, leaf characteristics and reproductive biology to live in the harsh environment (Tomlinson, 1986). Further, they exhibit peculiarities in seedling development and dispersal by way of vivipary. Vivipary is a functional characteristic defined as the precocious and continuous growth of the offspring when still attached to the maternal parent (Goebel, 1905); it is the norm in true mangrove plants (Tomlinson, 1986). There are two types of vivipary, true and crypto-vivipary. 
True vivipary refers to a situation where embryo penetrates through the fruit pericarp and grows to a considerable size before dispersal, while crypto-vivipary is a condition in which the embryo grows continuously, but does not emerge from the fruit before dispersal. These peculiar seedling characteristics present in mangrove plants could be adaptive features to overcome the harsh tidal environment for seedling establishment (Elmqvist and Cox, 1996). Therefore, reproductive biology of mangrove plants is central to understanding the structural and functional components of mangrove forests. Further, this knowledge is essential for the restoration of degraded mangrove areas.

The focus on the reproductive biology of mangrove plants has almost exclusively been on the fruit, seed or seedling dispersal stage. Surprisingly, less is known about floral biology, pollination, breeding systems and success rate of propagule production, although knowledge of the effectiveness of floral mechanics and genetic isolating mechanisms is an important prerequisite to the study of successful dispersal and establishment (Juncosa and Tomlinson, 1987; Clarke and Meyerscough, 1991; Ge et al., 2003; Chiou-Rong et al., 2005; Coupland et al., 2006). In India, a few studies provide some preliminary accounts of floral biology and pollination in some mangrove plants (Solomon Raju, 1989; Solomon Raju et al., 1994; Subba Reddi and Solomon Raju, 1997; Pandit and Choudhury, 2001; Solomon Raju et al., 2006; Solomon Raju and Jonathan, 2008). Therefore, a more complete understanding of the reproductive biology of mangroves is useful, mainly due to the growing pressures on mangroves from coastal environment and for effective mangrove rehabilitation programmes.

The present study is an attempt to provide information on the reproductive ecology of the genera Ceriops, Rhizophora, Bruguiera (viviparous), Avicennia, Aegiceras, Aegialitis and Scyphiphora (crypto-viviparous), Excoecaria, Lumnitzera, Sonneratia, Xylocarpus, Brownlowia, Sarcolobus and Suaeda (non-viviparous) occurring in Godavari and Krishna mangrove forests in the state of Andhra Pradesh, India. Floral biology, sexual system, breeding system, floral rewards, pollinators and their foraging behaviour have been investigated in these plant species. Further, fruit and seedling ecology, dispersal strategies and establishment have also been studied in these species. This knowledge is of high value for understanding the reproductive biology of the studied plant species and for conservation and management of these species. This knowledge is also useful for the restoration of degraded mangrove areas.

\section{MATERIAL AND METHODS}

Flowering phenology was examined by conducting field trips at selected short intervals for study on all chosen plant species. Inflorescence flowering phenology was recorded by tagging some inflorescences that have not anthesed yet and then following them daily until they ceased anthesis permanently. Daily anthesis schedules and anther dehiscence schedules were carefully observed. Intrafloral events were recorded chronologically by marking some flowers at bud stage on different conspecific plants. The aspects included flowering stage, flower organs wilting order, sepal/petal development, stamens and stigma stages and nectar production. Pollen output per anther/flower was determined as per the method given by Dafni et al. (2005). Ovule counting was made by crushing the pistil or splitting it gently and longitudinally with a blade on a glass slide spotted with lactophenol cotton blue and counting the ovules under a dissecting microscope. With the obtained pollen output and ovule number per flower, pollen-ovule ratio was determined. Stigma receptivity was examined visually and by $\mathrm{H}_{2} \mathrm{O}_{2}$ tests (Dafni et al., 2005). The amount of nectar secreted per flower was measured and expressed as $\mu \mathrm{l}$ of nectar/flower. The nectar sugar concentration was measured by using a Hand Sugar Refractometer (Erma, Japan) (Dafni et al., 2005). Nectar analysis for sugar types was done as per the paper chromatography method of Harborne 
(1973). Nectar analysis for amino acid types was done as per the paper chromatography method of Baker and Baker (1973). Breeding systems were investigated by following the protocols given by Dafni et al. (2005). Different sets of inflorescences prior to their flowering were used for determining natural fruit set rates.

Foraging schedule and forage type collected by flower visitors were observed following the methods of Solomon Raju (1989). Observations on foraging behaviour versus pollination by flower visitors were made visually. To judge the foraging activity of flower visitors, the total foraging visits of each species for the day on certain plant species were expressed in percentage. Based on this data, the percentage of foraging visits made by each species for the day was calculated. Field observations were also made regarding seed dispersal modes and subsequent establishment in mangrove forest.

\section{RESULTS}

Ceriops tagal (Rhizophoraceae). It is an evergreen shrub/tree that flowers during November-February. The flowers are born in condensed short-stalked cymes formed from dichotomizing panicles, which arise from the axils of leaves on the terminal nodes of new shoots. Flowers are short-stalked, small, white, cup-shaped, strongly fragrant, bisexual and zygomorphic. Sepals are five, small, yellowish green, valvate enclosing the inner parts until anthesis and not reflexed after anthesis. Petals are five, free, white, pubescent, two lobed, and alternating with the sepals. The lower margins of adjacent petals are held together by patches of tightly intertwining, helically coiled hairs. Each petal has three distinct clavate appendages on its distal margins. Stamens are ten, five of them antisepalous, five others antipetalous and all ten inserted on the rim of the calyx cup. Each petal encloses the antipetalous stamen and an adjacent antisepalous stamen; the two stamens remain in the petal under tension enclosed above by the clavate appendages even after anthesis. Style is slender and terminated into minute separate stigmatic lobes. The stigma stands at the height of the stamens. Disc within the stamen ring is well developed and anther lobes enclose the base of the thick filaments. Ovary is semi-inferior, three-carpelled and three-locular with a total of six ovules.

The mature buds open between $16^{30}-18^{00} \mathrm{~h}$. The calyx lobes separate at anthesis and diverge to expose the petals. The petals with the stamens inside, two per petal do not unfold naturally throughout the flower life, but remain in a tension with the spring-loaded stamens hooded above by clavate appendages. Anther dehiscence occurs in the bud. Pollen grains are triangular, light yellow, exine smooth and $15 \mu$ in diameter. A flower produces $14,681 \pm 25.62$ pollen grains. The pollen-ovule ratio is $2,446: 1$. The stigma attains receptivity on the second day and remains receptive up to six days. But, peak receptivity occurs in third-fifth day. In this period, the white petals turn red gradually from the top to the base. A flower produces $5.65 \pm$ $1.0 \mu \mathrm{l}$ of nectar. The nectar sugar concentration is $35-50 \%$ and the common sugars include fructose, sucrose and dextrose with the first relatively more dominant. The nectar contains 12 amino acids which include tyrosine, glycine, methionine, proline, lysine, aspartic acid, glutamic acid, serine, cysteine, alanine, threonine and arginine. Of these, glycine, serine, cysteine, alanine and threonine are relatively dominant. The amino acids such as phenylalanine, valine, leucine, iso-leucine, tryptophan and histidine were not found in the nectar. The unpollinated flowers fall off on the seventh day. In pollinated flowers, the petals, stamens, the style and stigma drop off in this order in three-four weeks, while the fruit is in a growing stage. The sepals are persistent, become warty and spiny gradually and remain on the plant even after the shedding of propagules. 
The buds produced proceed to open without abortion. In open flowers, abortion rate is $42 \%$. Of the twenty inflorescences bagged, eight flowers set fruits and, thus, the fruit set in bagged flowers is $3 \%$. Of the sixty four open inflorescences tagged, only 115 flowers set fruit, constituting 16.3\% natural fruit set. Fruit set per inflorescence varied from one to five but one and two-fruited inflorescences were more common. The pollinated flowers take four weeks to produce mature fruits with only one seed. Fruits are conical by the extrusion of the upper part of the ovary, with brown and roughened surface. The seed has no dormancy and produces hypocotyls while on the mother tree in a span of about two months. The cotyledonary yellow cylindrical collar appears from the fruit about ten days prior to detachment of the hypocotyls. The hypocotyl is $26 \mathrm{~cm}$ long, distinctly ridged and hangs downwards. It is initially green, after the development of the collar, it shows a gradual colour change to brownish purple from hypocotyl end to plumule. The mature hypocotyls separate from the fruit, leaving the latter attached to the mother plant. The detached hypocotyls were found to settle in the vicinity of the mother plant.

The flowers do not expose the stamens naturally but the latter attains tensed condition in the delicate petals for release by a delicate external touch. The foragers included honeybees, Apis cerana indica, A. florea, the fly, Chrysomya megacephala and the butterfly Tirumala limniace. They showed foraging activity throughout the day but with varying percentage of foraging visits and also species-wise, the percentage of foraging varied (Fig. 1).

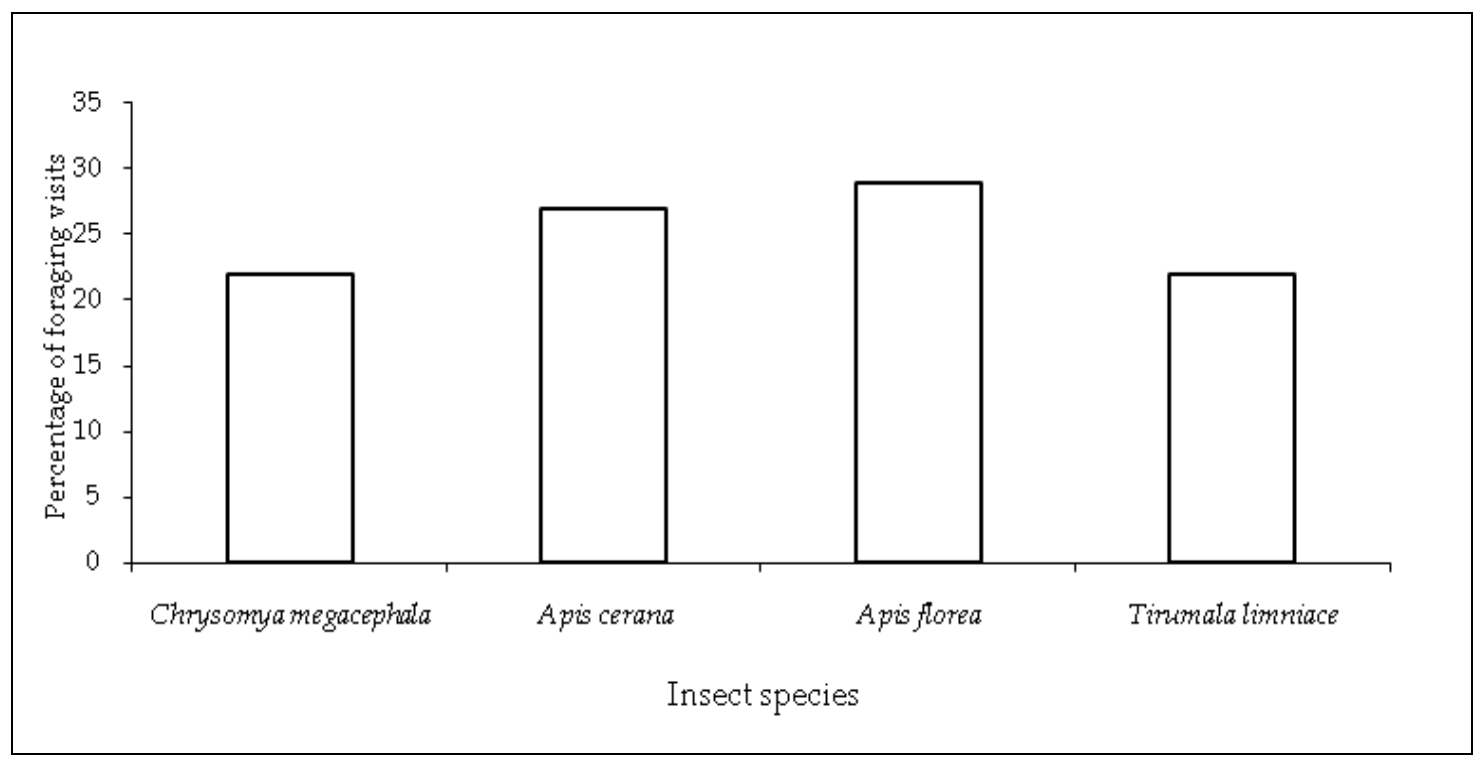

Figure 1: Percentage of foraging visits of insect species on Ceriops tagal.

Of these, honeybees foraged for pollen and nectar occasionally while the fly and butterfly foraged for the nectar consistently until the floral source exhausted. All the species approached the flower from above and probed for nectar, causing a sudden release of stamens from the petals. In effect, the pollen from the already dehiscent anthers was ejected forcibly and deposited on the underside of the foraging bee or fly. Body washings for pollen revealed the presence of pollen grains which varied from 231 to 413 per bee and from 79 to 147 per fly, suggesting that both bees and the flies have an important role in petal explosion and pollination. In case of bees, they also carried pollen loads in pollen baskets present on their legs. As each petal is independently enclosing two stamens, a single foraging visit of the bee or 
fly did not result in the explosion of all five petals. Both the bees and the fly tended to visit more than one flower on the same inflorescence or different inflorescences on the same plant before flying away to visit the neighbouring trees and may return back again to visit the same flowers later. As they tended to move back and forth between trees, their foraging activity may result in substantial self- and cross-pollination. The honey bees were found to concentrate principally on Bruguiera gymnorrhiza and Aegiceras corniculatum, while the fly species exclusively on Ceriops tagal. The explosion of petals in open flowers was also triggered by the action of wind. The plant grows in the seaward zone and hence high winds are the characteristic of the site. Of the twenty four flowers observed, four flowers had shown petal explosion triggered by wind action indicating that $16.6 \%$ of flowers may achieve pollination by wind action. In such flowers also, the explosion of all five petals did not take place at one time. It had not been possible to study whether wind could trigger petal explosion in the flowers located on the branches facing landward direction and mixed with the canopy where wind becomes relatively ineffective. Wind triggered petal explosion may result in autogamy.

Ceriops decandra (Rhizophoraceae). It is an evergreen, semi-understory, and small to moderate tall tree with perfect flowers. It produces numerous branches from the main stem. A typical tree of 1.5 meters contains as many as 20-21 primary branches and each primary branch bears 11-15 secondary branches. It occurs mainly in the inside of the mangrove vegetation and certain individuals occur along the creeks/estuarine banks. The tree shows budding, flowering and fruiting continuously throughout the year but there is a burst of concentrated flowering during November. Some young trees show alternate flowering and fruiting phases. The production rate of flowers and fruits are more robust on trees growing in the interiors of the forest when compared to those on trees growing along the creeks/estuarine banks. The flowers are borne in condensed cymes formed from dichotomizing panicles, which arise from the axils of leaves. The mechanical and biological features of this type of inflorescence provide continuous protection for the youngest units by a successive series of bracts, bracteoles and sepals. An inflorescence produces 5-31 flowers depending on the number of divisions of inflorescence axes. The cymes with more number of flowers are more common on the trees growing in the inner mangrove vegetation. The inflorescence takes sixten days to complete its flowering life. Flowers are small, white, cup-shaped, odorless, bisexual and zygomorphic. Sepals are five, free, small, light green, six mm long, valvate enclosing the inner parts until anthesis and not reflexed after anthesis. Petals are five, free, two-lobed, alternating with the sepals, five mm long, light green in mature bud stage and white at anthesis. They are inter-locked marginally by basal short hairs and this circumstance produces a short corolla tube crowned by the series of clavate filamentous appendages. Stamens are ten, five of them antesepalous, five others antepetalous and all ten inserted on the rim of the calyx cup. Each stamen is two mm long, free and extends beyond the height of the stigma; the filaments are green, while anthers are light brown, dorsifixed and longer than filaments. Disc within the stamen ring is well developed and anther lobes enclosing the base of the stamens. The ovary is semi-inferior, three-carpelled and three-locular with a total of six ovules. Style is slender, green, one mm long and terminated into minute separate stigmatic lobes.

The mature buds open during $04^{30}-11^{00} \mathrm{~h}$. The calyx lobes separate at anthesis and diverge to expose the petals, which adopt various configurations. Anther dehiscence occurs at anthesis. Pollen grains are ovate, triangular, light yellow and $16.6 \mu \mathrm{m}$ in diameter. A flower produces $12,810 \pm 30.87$ pollen grains. The pollen-ovule ratio is $2,135: 1$. The stigma attains receptivity about six hours prior to anthesis and remains receptive up to six days; but very 
active receptivity occurs in one-day and two-day old flowers. The stigma receptivity is notable even after six days but that receptivity appears to be non-functional in terms of pollen germination. Nectar is produced in trace amounts. The petals and stamens fall off on the seventh day of flower life. The sepals are persistent, become warty and spiny gradually and remain on the tree even after the shedding of propagules. The style and stigma dry up and drop off after ten days in fertilized flowers. The flowers that were not pollinated fall off on the fourth day.

Hand pollination tests for breeding system indicated that $C$. decandra fruits through xenogamy only; the fruit set rate is $92 \%$. Bud and flower abortion rate is $42 \%$ and $31 \%$ respectively. In open-pollinations, the fertilized flowers did not show a premature fruit drop. Fruit set per inflorescence varies from one-fur but not fruited inflorescences are more common. The pollinated flowers produce mature fruits in 50-55 days. Fruits are light green, $1.5 \mathrm{~cm}$ long, ovoid, conical and blunt apically. They are distinct with five-lobed persistent calyx and produce a single seed only. The embryo has no dormancy and penetrates through the seed coat and the fruit pericarp and grows to a considerable size into a spindle-shaped hypocotyl structure before dispersal while still attached to the maternal parent. This type of hypocotyl growth constitutes true vivipary. The hypocotyl grows upright and takes 85-90 days before detachment from the fruit. It is slender, clearly ribbed, angular, sulcate, $15 \mathrm{~cm}$ long and broadened at the lower end. Usually, they are entirely green and occasionally purple on one side; rarely yellow hypocotyls are also produced. The green hypocotyls seem to have the potential to photosynthesize actively with water and necessary nutrients drawn from the parent tree. The purple and yellow hypocotyls seem to lack chlorophyll partly or wholly and hence doubtful that they will have a successful establishment when detached from the parent tree. Very rarely, a single fruit produces two hypocotyls which may have arisen from two seeds resulting from two ovules out of actual six ovules per flower. In fully grown hypocotyls, fruit is separated from collar which emerges shortly before detachment. The fruit set rate per inflorescence shows a pattern in accordance with the number of flowers produced and area where the tree grows within the mangrove forest. An inflorescence produces one-six fruits. The trees growing near creeks/estuarine banks produce one-four fruits per inflorescence, onefruited ones being $51 \%$, two-fruited $34 \%$, three-fruited $12 \%$ and four-fruited $3 \%$. The trees growing in the inner mangrove areas produce one-six fruits per inflorescence, two-fruited ones are $45 \%$, three-fruited $26 \%$, one-fruited $22 \%$, four-fruited $5 \%$ and five-fruited and six-fruited, $1 \%$ each.

The foragers included Nomia sp., Ceratina simillima (bees), Odynerus sp. and Polistes sp. (wasps). The bees were quite common during September-October, while the wasps during November-December. The bees were found to collect nectar and pollen, while the wasps only nectar. These foragers visited the flowers during $10^{30}-16^{30} \mathrm{~h}$, more frequently during $13^{00}-14^{00}$ $\mathrm{h}$ coinciding well with the availability of the number of flowers, because anthesis period is relatively lengthy and the new flowers with nectar and pollen accumulate by that time. Nomia and Odynerus species made more percentage of foraging visits (Fig. 2). Bees approached the flowers in an upright position, landed in the cup-shaped flowers and probed for nectar and pollen in the same or different foraging visits. In doing so, their ventral side contacted the stamens first and then stigma effecting pollination. During pollen collection, these bees rotated around the flower to collect pollen from the anthers, which are situated in one whorl against the sepals and petals. They took three-five seconds to collect the forage from each newly opened flowers and two-three seconds from differently aged flowers. Their body washings for pollen revealed that they carry $1262.7 \pm 428.7$ (Range 35-1570) pollen grains and hence have an important role in pollination. In addition to this pollen, they also carried pollen loads in 
pollen baskets present on their legs. The bees were found to move between trees of $C$. decandra to collect both nectar and pollen and this inter-tree movement was considered to effect cross-pollination. As the number of new flowers per day is small in number, the bees were forced to collect forage from different trees of $C$. decandra and this flowering strategy is expected to promote cross-pollination. Wasps are about the size of a fly and construct their nest cells in sand heaps or in cavities of trees, lining them with agglutinated grains of sand or mud. The female wasps are known to feed on floral nectar after mating for the maturation of the eggs. The wasps observed on $C$. decandra collect nectar and such wasps were considered to be females. The study shows that $C$. decandra is a potential nectar source for female wasps. Wasps approached $C$. decandra flowers in an upright position, landed on the cymes, gradually moved to individual flowers and probed for nectar. They were found to move between individual trees in quest of more nectar. While probing the flower, they contacted the stamens and stigma with their underside and this resulted in pollination. The body washings for pollen indicated that they are pollen carriers; the pollen carry over ranges of eight to 49 . The number of bees and wasps visiting the flowers vary in different months, but both species occur continuously. Considering the changing number of bees and wasps in different months, both categories seem to be equally important as pollinators. The stigmatic pollen loads were analyzed to evaluate the rate of pollen deposition per stigma. The analysis indicated that each stigma receives $40.60+37.21$ (Range 5-170) pollen grains in open-pollinations but how much of it is xenogamic pollen is not known. The pollen deposition rate from the flowers was also analyzed to evaluate the role of foragers (after four-five flower visits) to empty the anthers and subsequent transportation to the receptive stigmas. The analysis showed that 10,243.7+ 1735.6 (Range 7660-12,400) pollen grains were depleted against the pollen output by 12,810 per flower suggesting that both bees and wasps are capable of transferring pollen and effecting pollination very effectively.

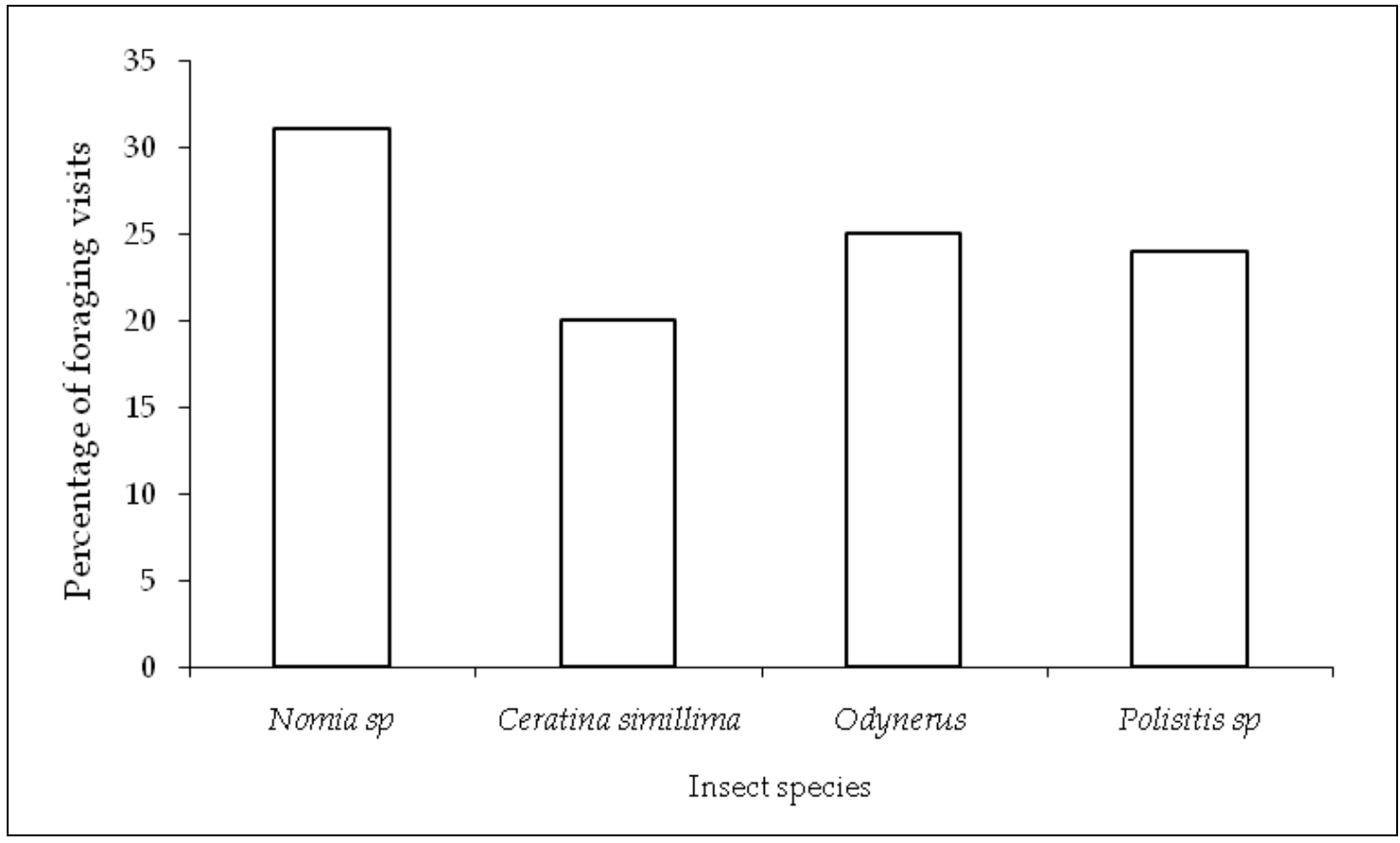

Figure 2: Percentage of foraging visits of insects on Ceriops decandra. 
Field studies indicated that $C$. decandra is used as firewood and for the constructions. Further, this species is important for its reddish brown coloured bark. The bark is known for its high tannin content ranging from 68 to $75 \%$ and dyeing with this tannin gives brown colour. The fishermen extract a reddish liquid from the bark and use it to protect cotton fishing nets from decay for a longer period. Some fishermen are involved in the trade of this bark and wood to make up their livelihood. About $80 \%$ of fishermen in 30 shore-based villages adjacent to the Godavari Delta mangrove forests depend on fishing activity for their livelihoods. They use mostly cotton nets for catching fishery sources in backwaters, while nylon nets for fishing activity in open sea water. The advantages of cotton nets include inexpensiveness and readily available because they are made locally. Nylon nets are not readily available and they are also expensive. The treatment of cotton nets is necessary to prevent damage to cotton threads due to soaking in saline water and to extend the length of its durability.

Rhizophora apiculata (Rhizophoraceae). It is a medium to tall evergreen tree with profusely spreading branches, growing to a height of more than 10-12 m. The leaves are large and dark glossy green. It flowers throughout the year with profuse flowering during AugustSeptember. Flowers are borne in pairs on a stubby axis, borne below the leafy crown, that is, in the axil of a leaf scar. They are sessile and erect in position. Flowers are light yellow, 8-12 mm long, 10-14 mm wide, cup-shaped, odourless, bisexual and zygomorphic; they are situated below the leaf clusters. Calyx is characteristically hard, yellow to brown, six-eight mm long and three-four $\mathrm{mm}$ wide, basally cup-like, with four sepals pointed towards apex and persistent. Petals are four, alternating with sepals, five-seven $\mathrm{mm}$ long, creamy-white, odourless, lanceolate, glabrous and delicate. Stamens are 12, sessile, dull white to dull brown, free, anthers are five-six mm long, bilobed, introrse and sagittate. The ovary is inferior, globose with two carpels each with two glabrous ovules on axile placentation; style is thick and short, creamy white, with two creamy white to light pink stigmatic lobes.

The mature buds open at $10^{00}-11^{00} \mathrm{~h}$; the sepals diverge least but expose the inconspicuous petals and sex organs. The petals remain flat and do not recurve. The anthers are multicellar, dehisce introrsely via the adaxial flap which falls against the base of the style in mature bud stage. The glabrous petals do not accumulate pollen from the dehisced anthers. Stigmatic lobes are appressed in mature bud and diverged gradually after anthesis; the diverged state of stigmatic lobes indicates the commencement of receptivity and ceases around noon of the second day. The stigma has no special modifications to capture the wind borne pollen but it is thickly coated with pollen even in mature bud. The style and stigma fall off after fruit initiation. The stamens and petals drop off on the second day. The calyx remains attached to the growing fruit, expands and reflexes backward. The pollen output per anther is 46,527.1 \pm 2,411.9 (Range 42,681-49,854) and per flower is 5.58.326. Pollen grains are tricolporate, dullwhite, powdery, ornamentation finely reticulate, the reticulum becoming progressively less distinct from pole to equator and $16.6 \mu \mathrm{m}$ diameter. The pollen-ovule ratio is 1.39.581:1. The pollen protein content per anther is $8.6 \mu \mathrm{g}$ and per flower is $104 \mu \mathrm{g}$. Nectar is secreted in trace amount around the ovary. The results of breeding systems indicate that the flowers are selfcompatible and self-pollinating. The fruit set is $72.5 \%$ in spontaneous autogamy, $86 \%$ in handpollinated autogamy, $92 \%$ in geitonogamy, $93.3 \%$ in xenogamy and 55\% in open pollination.

The flowers release pollen into the air; the sepals and petals in open flowers sprinkled with pollen due to wind action. A delicate manual disturbance to the flowers resulted that caused the release of a cloud of pollen out of the flower. Bees were the exclusive foragers and they were Nomia sp., Trigona iridipennis and Halictus ligatus. They foraged during day time from $08^{00}-17^{00} \mathrm{~h}$ for pollen and nectar from partially and completely opened flowers. Their 
foraging activity was consistent during profuse flowering period while it is sporadic at other times of the year. Of the total number of foraging visits of bees, $H$. ligatus made $44 \%$ followed by Nomia $41 \%$ and Trigona 15\% (Fig. 3). These bees first landed on the sepals, then investigated the flower for pollen and nectar; while doing so, their head and ventral side of the body touched the stamens and stigma and in the process they got coated with pollen. Further, they loaded pollen into pollen baskets. As all three bee species are pollen collecting bees, they made frequent visits to flowers situated on different plants which are closely and distantly spaced in order to collect more pollen. The fresh flowers available per day on a given tree are small in number and the bees made visits to different trees to collect more forage from as many flowers as possible. Further, the body washings of the bee species revealed the presence of pollen; the average number of pollen grains per bee for each species varied from 561.6 to 1006.9. It was found that thrips breed in buds and emerge when a flower opening occurs. They collected both pollen and nectar. During August-September, a single mature bud was usually found to contain many thrips moving out of the floral base when disturbed manually. Thrips were found to effect pollination as they moved in the entire flower touching the stigma.

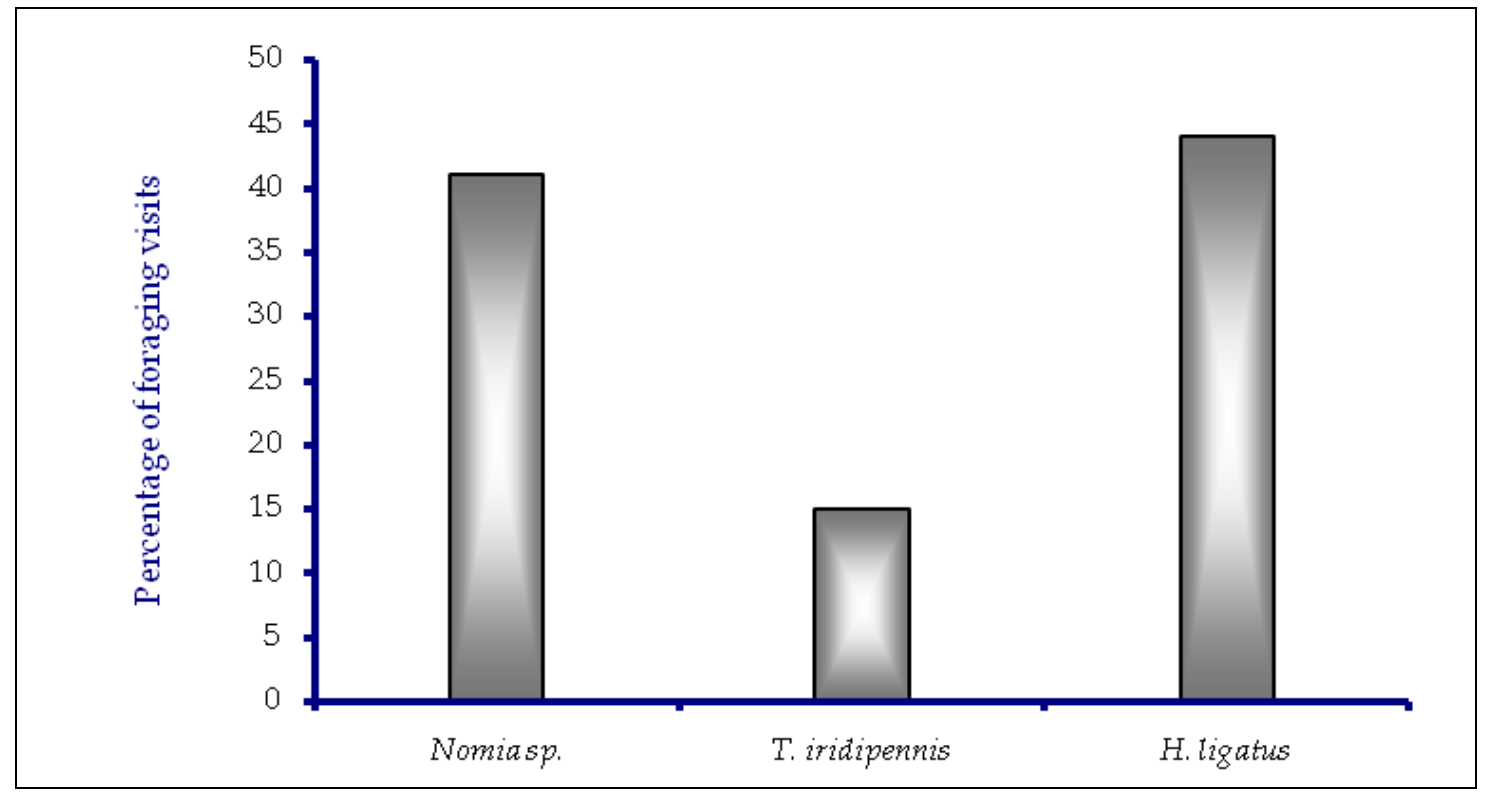

Figure 3: Percentage of foraging visits of bees on Rhizophora apiculata.

Pollinated and fertilized flowers initiate fruit development immediately and take 35 days to produce mature fruits. Of the four ovules in a flower, one ovule produces seed. Fruit is one-seeded with persistent light green calyx. A fruit producing two seeds and hence two hypocotyls is a rare occurrence. The seed produces $550 \mathrm{~mm}$ long, cylindrical elongate, light green, hypocotyl with a sharp end in a time span of 55-60 days. A light brown collar emerges between fruit and hypocotyl about a month prior to the detachment of the latter. The persistent calyx and fruit part remain in place on the parent tree while the hypocotyl detaches at the collar for dispersal. The hypocotyls fall and anchor vertically in the substratum at low tide when the forest floor gets exposed; they float in water and disperse by tidal currents at high tide until settled in the mud. The radicle side of hypocotyl penetrates the soil and produces root system while plumule side produces new leaves and subsequent aerial system. 
Rhizophora mucronata (Rhizophoraceae). It is a medium to tall evergreen tree with profusely and horizontally spreading branches, growing to a height of more than $15 \mathrm{~m}$. It flowers during June-November. The inflorescence is a four-flowered pedunculate dichotomized cyme borne in leaf axils; the flowers are pedicellate, pendulous and hanging downwards. Flowers are creamy white, $15 \mathrm{~mm}$ long, $10 \mathrm{~mm}$ wide, cup-shaped, odourless, bisexual and zygomorphic; they are situated below the leaf clusters. Calyx is characteristically hard, creamy white, $12 \mathrm{~mm}$ long and seven mm wide, basally cup-like, with four sepals pointed towards apex and persistent. Petals are four, alternating with sepals, ten mm long, white, hairy, odourless, lanceolate, and delicate. Stamens are eight, sessile, four opposite to petals, another four opposite to sepals, dull white to dull brown, free, anthers are seven mm long, bilobed, introrse and sagittate. Ovary is semi-inferior, globose with two carpels each with two glabrous anatropous ovules on axile placentation; style is thick and short, creamy white, with two creamy white to light pink stigmatic lobes.

The mature buds open at $10^{00}-16^{00} \mathrm{~h}$; the sepals diverge gradually exposing the petals and sex organs. The petals also diverge and slightly reflex backwards. The anthers are multilocellar, dehisce introrsely via the adaxial flap which falls against the base of the style in mature bud stage. The hairy petals accumulate pollen from the dehisced anthers. Stigmatic lobes are appressed in mature bud and diverged gradually after anthesis; the diverged state of stigmatic lobes indicates the commencement of receptivity and ceases around noon of the second day. The stigma has no special modifications to capture the wind borne pollen, but it is thickly coated with pollen even in mature bud. The style and stigma fall off after fruit initiation. The stamens and petals drop off on the second day. The calyx remains attached to the growing fruit, expands and reflex backwards.

The pollen output per anther is 34,986.6 527.34 (Range 34,007-35,729) and per flower is 2,79,893. Pollen grains are tricolporate, dull-white, powdery, and $24.9 \mu \mathrm{m}$ long and $12.2 \mu \mathrm{m}$ in diameter; their surface sculpture is rather smooth, with numerous small and shallow depressions. The pollen-ovule ratio is 69,973.2:1. The pollen protein content per anther is $10.2 \mu \mathrm{g}$ and per flower is $82 \mu \mathrm{g}$. Nectar volume per flower is $1.03 \pm 0.26 \mu \mathrm{l}$ (Range 0.8-1.5) and accumulated around the ovary. The results of breeding systems indicate that the flowers are self-compatible and self-pollinating. The fruit set is $52.5 \%$ in spontaneous autogamy, $63.3 \%$ in hand-pollinated autogamy, $71.4 \%$ in geitonogamy, $85 \%$ in xenogamy and $53.3 \%$ in open pollination.

The flowers release pollen into the air; the sepals and petals in open flowers were found to be sprinkled with pollen due to wind action. A delicate manual disturbance to the flowers resulted caused the release of a cloud of pollen out of the flower. The flowers were foraged consistently during day time from $08^{00}-17^{00} \mathrm{~h}$ exclusively by bees. The bees included Nomia sp., Trigona iridipennis, Halictus ligatus, Ceratina simillima and Xylocopa pubescens. An unidentified moth was also found to collect nectar occasionally. Bees collected both pollen and nectar from partially and completely opened flowers. Each bee species contributed $11-24 \%$ of total foraging visits (Fig. 4). These bees first landed on the sepals, then entered the flower to collect pollen and nectar; while doing so, their head and ventral side of the body touched the stamens and stigma and in the process they got coated with pollen. Further, they loaded pollen into pollen baskets. All the bee species except Xylocopa, are pollen collecting bees, they made frequent visits to flowers situated on different plants which are closely and distantly spaced in order to collect more pollen. Xylocopa bees are fast fliers and made inter-tree flight in quest of more nectar from as many flowers as possible. The fresh flowers available per day on a given tree are small in number and for this reason, the bees were compelled to make visits to different trees 
for more forage. Further, the body washings of the bee species revealed the presence of pollen; the average number of pollen grains per bee for each species varied from 189.3 to 951.6. Thrips breed in buds and emerge when flower opening occurs. They collected both pollen and nectar. A mature bud contained numerous thrips moving out of the floral base when disturbed manually. Thrips were found to carry pollen on their bodies and moving in the entire flower including the stigma during which they transferred pollen onto the stigma. The flowers with huge pollen production together with pollen characteristics described above were considered to be anemophilous. Further, the pollen being powdery was found to be dispersed easily due to wind action. A simple manual disturbance to flowers made the latter to release pollen into the air.

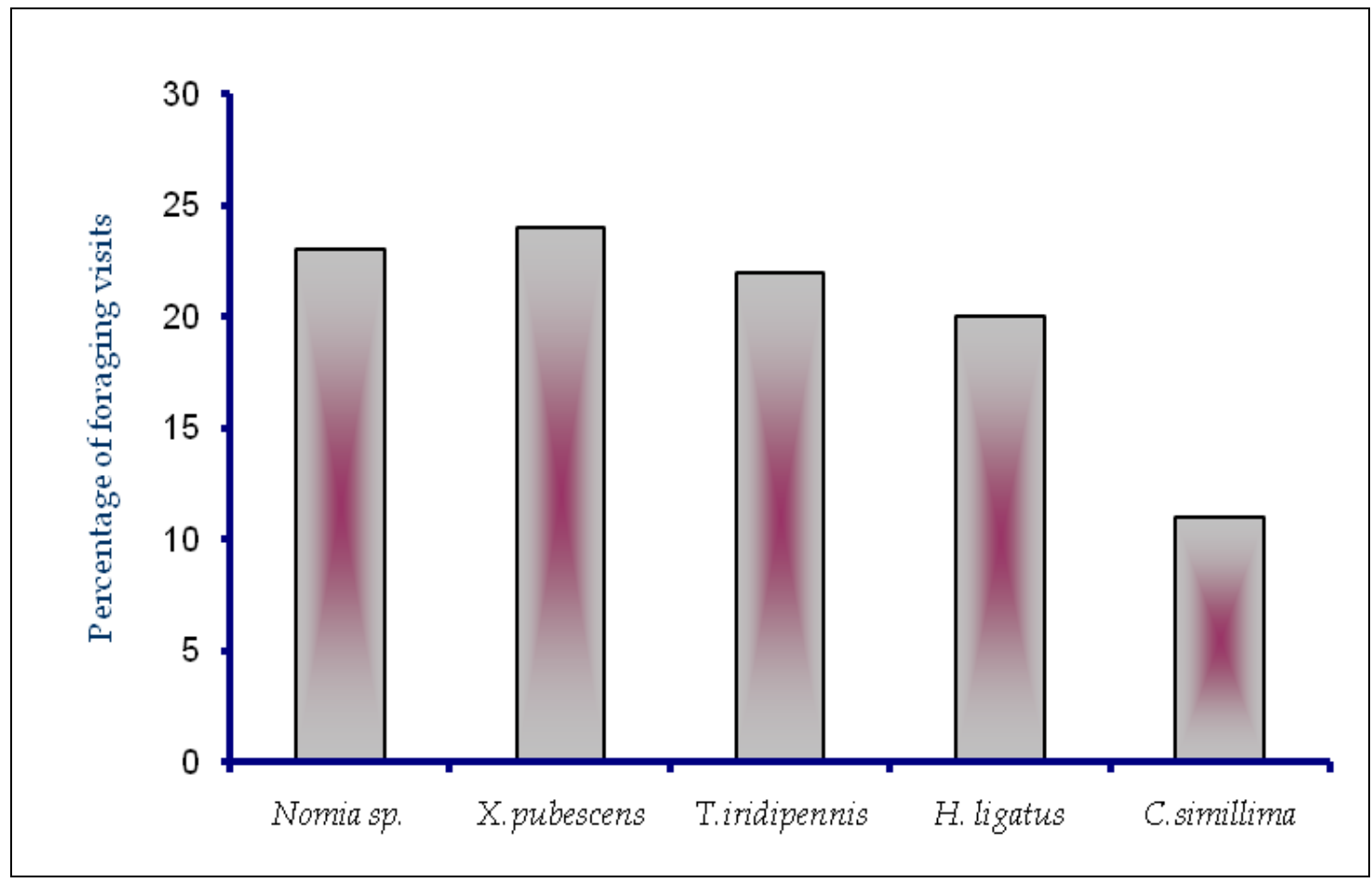

Figure 4: Percentage of foraging visits of bee on Rhizophora mucronata.

Pollinated and fertilized flowers initiate fruit development immediately and take 40 days to produce mature fruits. In fertilized flowers, only one ovule out of four ovules produced seeds. Fruit is one-seeded with woody, persistent light green and reflexed calyx. Seed produces $680 \mathrm{~mm}$ long, cylindrical elongate, light green, warty hanging hypocotyl in a time span of 6065 days. A light yellow tubular collar (20 mm long) emerges between fruit and hypocotyl about a month prior to detachment of the latter. The hypocotyl detaches at the collar for dispersal. Later, the entire fruit part also falls off. The hypocotyls settle in the substratum immediately at low tide when the forest floor gets exposed; they float in water and disperse by tidal currents at high tide until settled in the soil. The radicle side of hypocotyl penetrates the soil and produces root system, while plumule side produces new leaves and subsequent aerial system. The fruit also falls off eventually from the maternal parent. 
Bruguiera gymnorrhiza (Rhizophoraceae). It is a medium to tall evergreen tree with much diffused spreading branches, growing to a height of more than ten $\mathrm{m}$. It flowers throughout the year with profuse flowering during April-June. Flowers are solitary, single flower in each peduncle, located in the leaf axils, usually positioned at the first (or rarely second) node below the apical shoot. Flowers are pedicellate, typically recurved, pointing away from the terminal vegetative bud, pendulous, 30-35 mm long, 19-20 mm wide, pinkish to reddish white, tubular, odourless, bisexual and zygomorphic. Calyx is characteristically hard, smooth or with grooves above lobe junctures, pinkish to reddish white, basally cup-like, rarely ribbed, with 11-14 lobes, acutely pointed, narrow and persistent. Petals are 14, bilobed, $15 \mathrm{~mm}$ long and four mm wide, creamy-white in mature bud, orange-brown on maturation, delicate with marginal interlocking hairs, the tips of lobes acute commonly with three filamentous appendages distally usually with a rigid straight four $\mathrm{mm}$ long bristle between them. The base of each petal has a cluster of smooth silky hairs. Stamens are 28 enclosed in petal pouches, two stamens in each petal, filament creamy white, ten $\mathrm{mm}$ long and two $\mathrm{mm}$ wide, anthers are creamy white initially and turn to golden brown at maturity; bilobed and basifixed. Ovary is inferior, cup-shaped with six light brown, smooth ovules; style is slender, white to light brown, filiform with three or four, $15 \mathrm{~mm}$ long, whitish-yellow stigmatic lobes containing small papilla and secreting mucilage; the stigma remains attached to fruit at maturity.

The mature buds open at $07^{00}-09^{00} \mathrm{~h}$; the sepals diverge gradually presenting the closed, erect petals in the cocked position. The petals conceal the stamens in a tensed state due to the pressing of the latter against the interlocked margins of the petals. The petals bend back and remain in an erect position by the adherent ventral margins. Marginal hairs appear to be important in holding the petals in the folded position. The stamens dehisce in mature bud stage by longitudinal slits. The petal margins unzip instantaneously when triggered by external touch; then they fly apart releasing the stamens which catapult the loose pollen as a visible cloud toward the centre of the flower. If the external touch is caused by a forager, then much of the pollen would be projected onto the head and the body of the forager. Each petal explodes independently and hence multiple visits are required to trip all the petals of a flower. Individual flowers with combinations of closed and tripped petals were found. After the petal tripping, the petals lie back against the calyx lobes with empty stamens twisted and disorganized. Petals and stamens persist for up to seven days and eventually fall off as threefour units. Untripped petals retain their tension for up to eight days, and they eventually fall off without ever opening. Stigmatic lobes are receptive from second to fourth day and show signs of withering after the petals and stamens have fallen. The pollen output per anther is 9,005.4 \pm 834.95 (Range 8,004-10,469) and per flower is 2,51,856 pollen grains. Pollen grains are tricolporate, pale yellow, elliptic in equatorial view, circular in polar view, exine smooth with numerous small and shallow depressions, $29.6 \mu \mathrm{m}$ long and $16.6 \mu \mathrm{m}$ diameter. The pollenovule ratio is $41,976: 1$. The pollen protein content per anther is $1.77 \mu \mathrm{g}$ and per flower is 49.6 $\mu \mathrm{g}$. Copious nectar accumulates in the deep calyx cup and is retained by the petal base and its associated hairs. In newly open flowers, five-ten $\mu \mathrm{l}$ of nectar is secreted and it is continuously produced even after the abscission of petals and stamens in some flowers while it is not produced continuously in some other flowers. The flowers with the former situation were designated as un-pollinated ones while those with the latter situation were designated as pollinated flowers. A flower produces $10.49 \pm 5.2$ (Range 5.2 - 24) $\mu \mathrm{l}$ of nectar with a sugar concentration of $23.48 \pm 4.80 \%$ (Range 18-31); glucose and fructose were present. In unvisited flowers, it overflows onto the petals where it becomes viscous by evaporation and so inhibits the explosive mechanism. The total sugar content in the nectar of a flower is $2.58 \pm 1.20$ (Range 1.06-5.39) $\mathrm{mg}$. The nectar protein content per flower is $78.68 \pm 48.56 \mu \mathrm{g}$ (Range 44.8- 
192). The nectar contains eight amino acids which include alanine, aspartic acid, glutamic acid, arginine, histidine, lysine, glycine and serine. All these amino acids are abundant except lysine. The results of breeding systems indicate that the flowers are self-compatible and selfpollinating. The fruit set is $40 \%$ in manipulated autogamy, $60 \%$ in geitonogamy, $90 \%$ in xenogamy and $87 \%$ in open pollination.

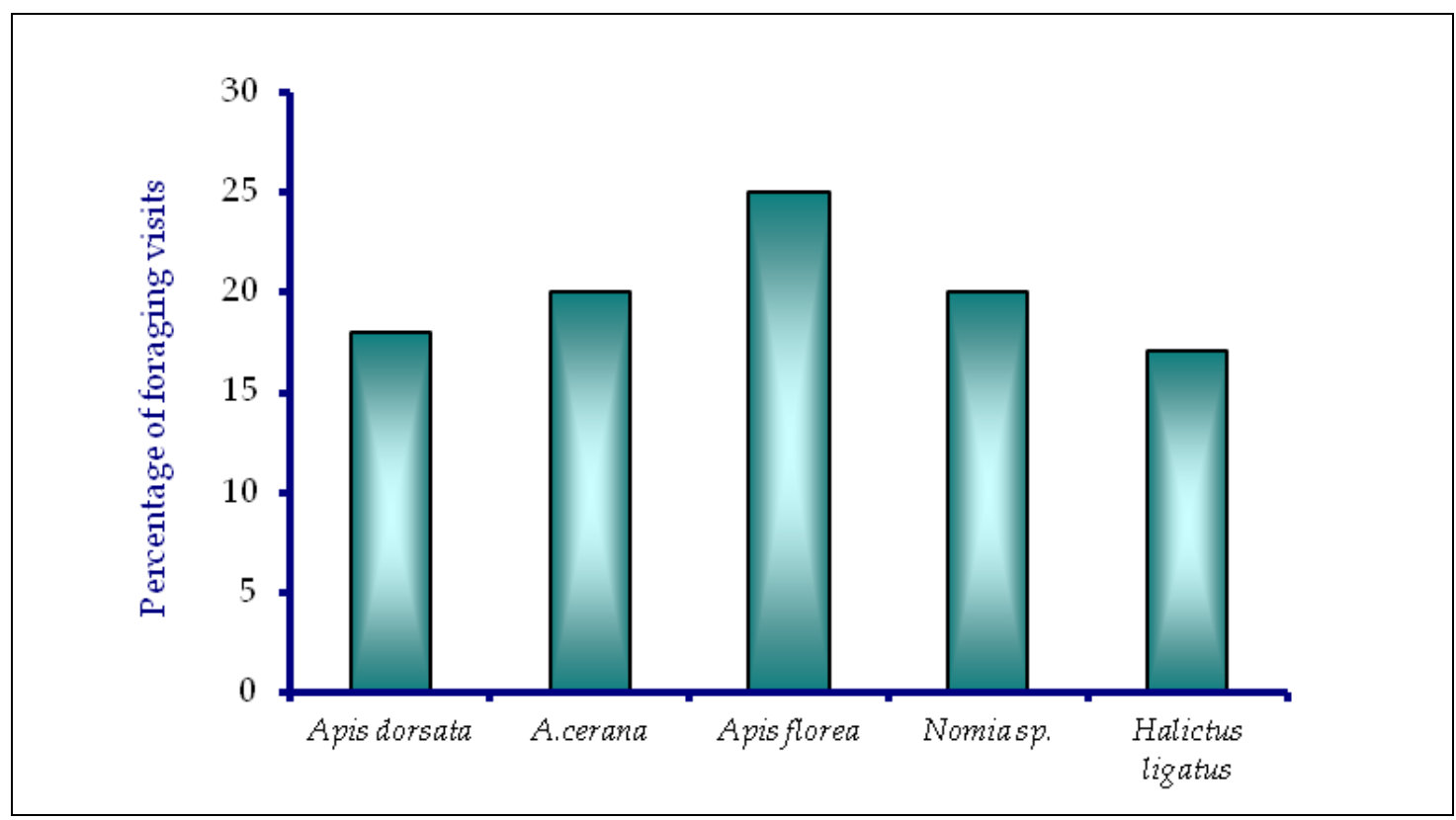

Figure 5: Percentage of foraging visits of bees on Bruguierra gymnorrhiza.

The flowers are characterized by explosive pollination mechanism. They were foraged consistently during day time from $07^{00}-17^{00} \mathrm{~h}$ exclusively by bees. The bees included Apis dorsata, A. cerana, A. florea, Nomia sp. and Halictus ligatus. Bees collected both pollen and nectar from partially and completely opened flowers. Of the total number of foraging visits of bees, A. florea contributed 25\%, A. cerana and Nomia each 20\%, A. dorsata $18 \%$ and $H$. ligatus 17\% (Fig. 5). All the bees turned their heads upward to collect nectar located in the calyx cup; while doing so, they tripped the tensed petals to release a cloud of pollen explosively without being disturbed by the explosion. A single foraging visit did not result in tripping all the petals at a time. Petal explosion was found to be effected by touching sensitive basal hairs, especially those which project in the centre of the flower over the entrance to the calyx cup. The tip of the petal and its apical appendages were not sensitive but petal tripping was stimulated by fairly vigorous probing into the calyx cup. The bees took different positions while probing and collecting nectar in relation to stamens and style. Each foraging visit invariably contacted the style and stigma and resulted in the deposition of pollen on the foraging bee. The bees were also found to collect nectar from empty flowers which are devoid of petals and stamens. They were found to move frequently between plants seeking more nectar and/or pollen as few rewarding flowers are available daily per tree. Such a foraging behaviour could make them as effective pollen dispersers causing both self- and crosspollination. Further, the body washings of all foraging bee species revealed the presence of pollen; the average number of pollen grains per bee for each species varied from 198 to 1,389. 
Pollinated and fertilized flowers initiate fruit development immediately and take 30-35 days to produce mature fruits. Fruit is one-seeded fleshy berry with persistent reddish calyx. Seed produces $141 \pm 9 \mathrm{~mm}$ long, cylindrical elongate, stocky, dark green, coriaceous hanging hypocotyl with blunt apex in a time span of 45-50 days. In a sample of 200 hypocotyls, 5\% were found to be damaged especially at the terminal part by the Rose-ringed Parakeet, Psittacula krameri; the damaged part was fleshy and hence eaten by the bird. The persistent calyx remains attached even after mature hypocotyl falls from the mother tree. The hypocotyls settle in the substratum immediately at low tide when the forest floor is exposed; they float and disperse by tidal currents at high tide until settled in the soil. The radicle side of the hypocotyl penetrates the soil and produces root system while plumule side produces new leaves and aerial system.

Bruguiera cylindrica (Rhizophoraceae). It is a medium to tall evergreen tree with diffused spreading branches, growing to a height of more than $12 \mathrm{~m}$. The flowering occurs during September-March. The inflorescence is a simple pedunculate dichasium cyme with pedicellate erect flowers; each cyme is three-flowered and borne in leaf axils. Flowers are greenish-white, 10-12 mm long, short-tubed, odourless, bisexual and zygomorphic. Calyx is tubular, funnel-like (five-seven mm long and two mm wide), smooth, light green, with seveneight pointed lobes, characteristically hard and persistent. Petals are seven-eight, initially creamy white, later turning to light brown from the tip towards the base, alternating with sepals, shortly bilobed, each lobe three $\mathrm{mm}$ long and one $\mathrm{mm}$ wide, delicate with marginal interlocking minute hairs, the tips of lobes acute commonly with three filamentous appendages distally usually with a rigid straight bristle between them. The base of each petal has a cluster of smooth silky hairs. Each petal encloses a pair of stamens, filament creamy white, two mm long and one mm wide, anthers are creamy white initially and turn to light brown at maturity; bilobed and basifixed. Ovary is inferior, cup-shaped, with four light brown, smooth ovules; style is slender, white to light brown, filiform with two creamy white to yellow stigmatic lobes, two mm, situated below the height of stamens, stiff and remains attached to fruit at maturity.

The mature buds open at $07^{00}-09^{00} \mathrm{~h}$; the sepals diverge gradually presenting the closed, erect petals in the cocked position. The petals conceal the stamens in tensed state due to the pressing of the latter against the interlocked margins of the petals. The petals are retained in an erect position by the adherent ventral margins. Marginal hairs appear to be important in holding the petals in the folded position. The stamens dehisce in mature bud stage by longitudinal slits. The petal margins unzip instantaneously when triggered by a delicate touch; then they fly apart releasing the stamens which catapult the loose pollen toward the centre of the flower. If the external touch is caused by a forager, then much of the pollen would be projected onto the head and body of the forager. Each petal explodes non-violently and independently. In an observed set of flowers, most flowers had all petals tripped. After the petal tripping, the petals lie back against the calyx lobes with the empty stamens twisted and disorganized. Petals and stamens persist for up to three days and eventually fall as three-four units. Untripped petals retain their tension for up to six days, and they eventually fall off without ever opening. Stigmatic lobes are receptive on the second and third day and show signs of withering after the petals and stamens have fallen. The pollen output per anther is $1,289.7 \pm 299.29$ (Range 1,021-1,828) and per flower is 20,635 pollen grains. Pollen grains are tricolporate, light yellow, powdery, ornamentation finely reticulate, the reticulum becoming progressively less distinct from pole to equator and $16.6 \mu \mathrm{m}$ long. The pollen-ovule ratio is 5,158:1. The pollen protein content per anther is one $\mu \mathrm{g}$ and per flower is $16 \mu \mathrm{g}$. Nectar accumulates in the deep calyx cup and is retained by the petal base and its associated hairs. A 
flower produces $1.43 \pm 0.31 \mu \mathrm{l}$ (Range 0.9-2) of nectar with a sugar concentration of $15.2 \pm$ $1.57 \%$ (Range 10-21); glucose, fructose, sucrose and maltose were present but the first sugar is dominant. The total sugar content in the nectar of a flower is $0.11 \pm 0.03$ (Range 0.04-0.17) $\mathrm{mg}$. The results of breeding systems indicate that the flowers are self-compatible and selfpollinating. The fruit set is $40 \%$ in unmanipulated autogamy, $56 \%$ in manipulated autogamy, $63.3 \%$ in geitonogamy, $80 \%$ in xenogamy and $64.4 \%$ in open pollination.

The flowers are characterized by explosive pollination mechanism. They were foraged consistently during $07^{00}$ to $17^{00} \mathrm{~h}$ by Nomia bee and the wasps, Odynerus sp. and Polistes humilis. The bee collected both pollen and nectar while the wasps collected only nectar. Of the number of foraging visits of bees, Nomia contributed 38\% while the remaining percentage by the wasps (Fig. 6).

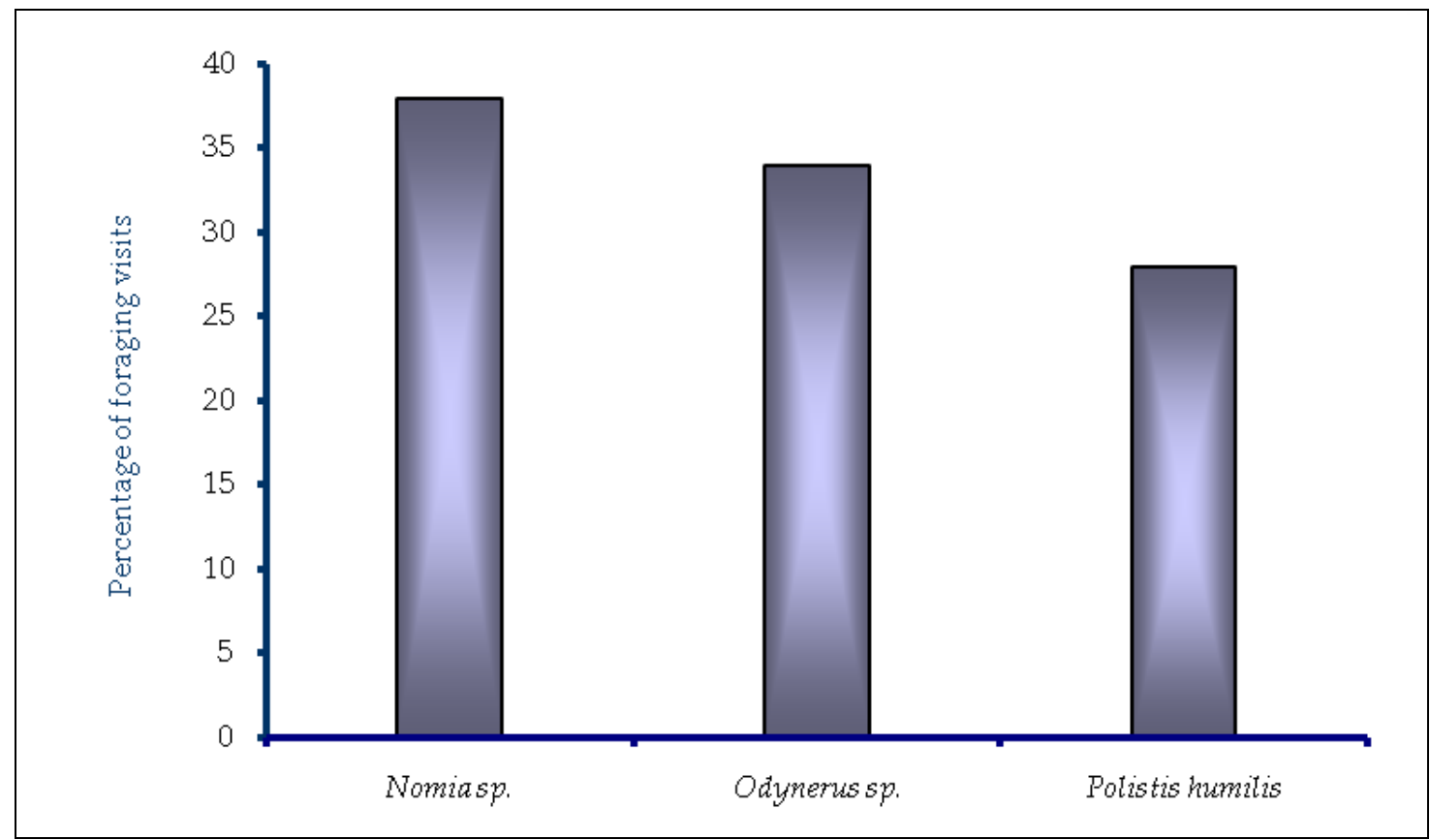

Figure 6: Percentage of foraging visits of insects on Bruguiera cylindrica.

These foragers approached the flowers in upright position and probed the flowers for nectar and/or pollen; they tripped the tensed petals without being disturbed by the explosion. One or two visits of the foragers resulted in the explosion of all flower petals. Petal explosion was found to be effected by touching sensitive basal hairs, especially those which project into the centre of flower over the entrance to the calyx cup. The tip of the petal and its apical appendages were not sensitive but petal tripping was stimulated by vigorous probing into the calyx cup. Each foraging visit invariably contacted the style and stigma and resulted in the deposition of pollen on the foraging bee. They were found to move frequently between plants seeking more nectar and/or pollen as few rewarding flowers are available daily per tree. Such a foraging behaviour could make them as effective pollen dispersers causing both self and cross pollination. Further, the body washings of all foragers revealed the presence of pollen; the average number of pollen grains per forager for each species varied from 262 to 448.2 . 
Pollinated and fertilized flowers initiate fruit development immediately and take 18-20 days to produce mature fruits. Of the four ovules, only one ovule produces seed in fertilized flowers. Rarely, two ovules produce seeds; in such fruits, twin hypocotyls are produced per fruit. Fruit is one-seeded, creamy white, $20 \mathrm{~mm}$ long; persistent creamy white calyx lobes stick out at right angles to the fruit. Seed produces $136 \pm 16 \mathrm{~mm}$ long, cylindrical elongate, slightly curved, green to purple, pendulous hypocotyl with blunt apex in a time span of 30-35 days. The persistent calyx remains attached after mature hypocotyl falls from the parent tree. The hypocotyls settle in the mud at low tide during which the forest floor gets exposed; they float in water and disperse by tidal currents at high tide. The radicle side of the hypocotyl produces root system while plumule side produces new leaves and subsequent aerial system.

Avicennia alba (Avicenniaceae). Small evergreen tree with irregular branches, growing to a height of more than 10-12 m. Following monsoon showers in June, it initiates flowering and continues flowering until the end of August. Individual trees flower for $35 \pm 4$ (Range 3248) days. Inflorescence is a terminal and axillary spicate raceme. An inflorescence produces, on average, $52.34 \pm 26.96$ flowers (Range 15-123) anthesing from the base to top over a period of 25 days (Range 24-28). The flowers are sessile, small (four mm long; three mm diameter), orange yellow, fragrant, actinomorphic and bisexual. Calyx is short, elliptic and has four ovate, green, pubescent, two $\mathrm{mm}$ long, one mm wide, sepals with hairs on the outer surface; it is persistent. Corolla has four thick, orange yellow ovate, four mm long and two mm wide petals forming a short tube at the base. Stamens are fur, epipetalous, one mm long, occur at the throat of the corolla. The anthers are dorsifixed, introrse and arranged alternate to petals. The ovary is very small (two mm long), flask-shaped, conspicuously hairy but lower part includes glandular hairs, bicarpellary syncarpous with four imperfect locules and each locule contains one pendulous ovule. It is terminated with a one $\mathrm{mm}$ long glabrous style tapered to the bifid hairy stigma. The light yellow style and stigma arise from the centre of the flower and stand erect throughout the flower life.

The mature buds open throughout the day but most buds opening during $09^{00}-12^{00} \mathrm{~h}$. The petals slowly open and take three-four hours for complete opening to expose the stamens and stigma. The petals emit fragrance at anthesis. The stamens bend inward overarching the stigma at anthesis and dehisce $1 / 2$ hour after anthesis. All the four anthers dehisce at the same time by longitudinal slits. The stigma is well seated in the centre of the flower. After anthesis, the stigma grows gradually and becomes bifid on the morning of the second day. The bifid condition of stigma is an indication of beginning of stigma receptivity and it remains receptive for two days. The stigmatic lobes recurve completely. A flower lasts for six days. The petals, stamens and stigma drop off while the calyx is persistent. The pollen production per anther is $1,967 \pm 31.824 .3$ (Range 1,929-2,010) and per flower is 7,868. The pollen grains are light yellow, granular, tricolporate, reticulate, muri broad, flat, thick; lumina small irregularly shaped, colpi deeply intruding and $24.9 \mu \mathrm{m}$ in size. The pollen-ovule ratio is 1,967:1. The flowers begin nectar secretion along with anther dehiscence. The nectar secretion occurs in minute amount which is accumulated at the ovary base and on the yellow part of petals; the nectar glitters against sunlight. A flower produces $0.5 \pm 0.1 \mu \mathrm{l}$ (Range 0.4-0.7) of nectar with a sugar concentration of $40 \%$. The sugar types included glucose and fructose and sucrose with the first as dominant. The results of breeding systems indicate that the flowers are selfcompatible and self-pollinating. The fruit set is $17.5 \%$ in spontaneous autogamy, $40 \%$ in handpollinated autogamy, $62.5 \%$ in geitonogamy, $64.28 \%$ in xenogamy and $42 \%$ in open pollination. 
The flowers were foraged consistently during day time from $07^{00}-17^{00} \mathrm{~h}$ by insects. The insects included Apis dorsata, A. florea, Nomia sp., Chrysomya megacephala, an unidentified fly, Danaus chrysippus and Everes lacturnus. The fly species visited the flowers in groups. The pollen was collected by bees only; they also collected nectar throughout the flower life depending on the availability. All other insects collected nectar only. Each forager species made $8.5-21 \%$ of foraging visits (Fig. 7). All the insects probed the flowers in upright position to collect the forage. Butterflies landed on the petals, stretched their proboscis to collect nectar aliquots on the petals and at the flower base. In this process, all the insects invariably touched the anthers and the stigma; the ventral side of all insects was found with pollen. Further, the body washings of the all insect species revealed the presence of pollen; the average number of pollen grains per insect for each species varied from 67.6 to 336.2. As the nectar is secreted in minute amount, the insects made multiple visits to most of the flowers on a tree and moved frequently between trees to collect nectar. Such a foraging behaviour was considered to effect self- and cross-pollination.

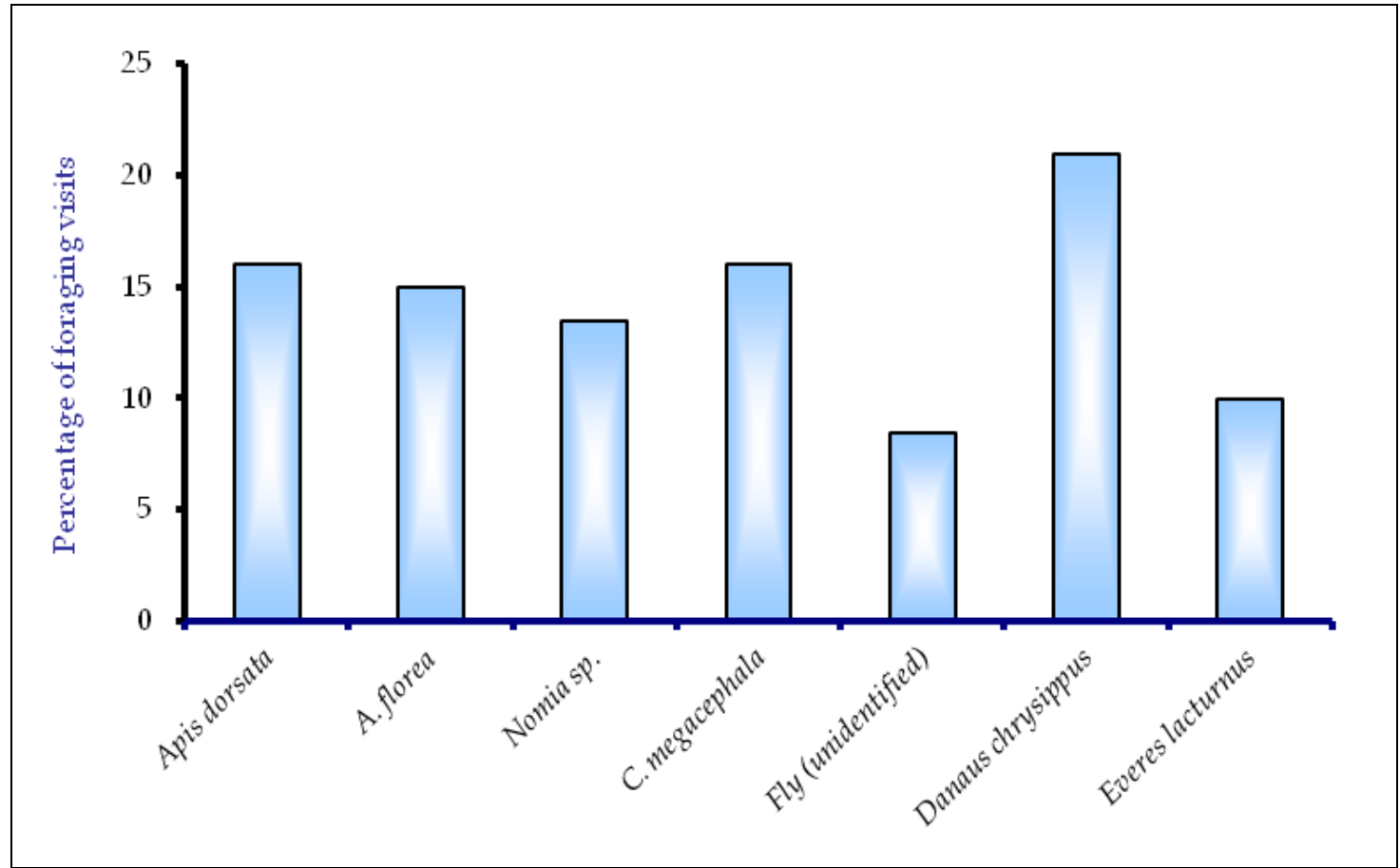

Figure 7: Percentage of foraging activity of insects on Avicennia alba.

Pollinated and fertilized flowers initiate fruit development immediately and take about five-six weeks to produce mature fruits. In fertilized flowers, only ovule produces seed. Fruit is a one-seeded leathery pale green capsule with persistent reddish brown calyx; $40 \mathrm{~mm}$ long, 15 $\mathrm{mm}$ wide, abruptly narrowed to a short beak and hairy throughout. Seed produces light green, hypocotyl which completely occupies the fruit cavity. An inflorescence produces three \pm one fruits (Range 1-5); one-fruited ones constituted 54\% followed by two-fruited ones (23\%) and three-fruited (10\%) and four-fruited (5\%) and five-fruited (2\%). Of these, $6 \%$ were damaged by the Rose-ringed Parakeet, Psittacula krameri; it was found to feed on the concealed hypocotyl in fruits and these fruits were subsequently empty. The fruit together with hypocotyl 
falls off the mother plant; it was found to settle in the substratum immediately at low tide period when the forest floor is exposed; it floats in water and disperses by tidal currents at high tide period until settled somewhere in the soil. The radicle side of hypocotyl penetrates the soil and produces root system while plumule side produces new leaves and subsequent aerial system. The fruit pericarp detaches and disintegrates when plumular leaves are produced.

Avicennia marina (Avicenniaceae). It is a small evergreen tree with irregular spreading branches, growing to a height of more than three-eight m. Following monsoon showers in June, it initiates flowering and continues flowering until the end of August. Individual trees flower in 32-35 days. Inflorescence is a compound axillary or terminal cyme. An inflorescence shoot produces, on average, $47 \pm 13.97$ flowers (Range 26-76) anthesing from the base to top over a period of 22 days (Range 15-22). The flowers are sessile, small (six $\mathrm{mm}$ long; five mm diameter), orange yellow, sweet scented, actinomorphic and bisexual. Calyx is short, elliptic and has four ovate light green, two mm long sepals with hairs on the outer surface; it is persistent. Corolla has four thick, orange yellow ovate four mm long and two mm wide petals forming a short tube at the base. The petals are glabrous inside and hairy outside. Stamens are four, epipetalous, two mm long, occur in the throat of the corolla. The anthers are basifixed, exserted, introrse and arranged alternate to petals. The ovary is very small (two mm long), conspicuously hairy, bicarpellary syncarpous with four imperfect locules and each locule contains one pendulous ovule. It is terminated with a one mm long glabrous style tapered to the bifid hairy stigma. The light yellow style and stigma arise from the center of the flower and stand erect throughout the flower life.

The mature buds open throughout the day but most buds open during $10^{00}-13^{00} \mathrm{~h}$. The petals slowly open and take two-three hours for complete opening to expose the stamens and stigma. The petals emit a sweet fragrance at anthesis. The stamens bend inward overarching the stigma at anthesis and dehisce half an hour after anthesis. All the four anthers dehisce at the same time by longitudinal slits. The stigma is well seated in the center of the flower. After anthesis, the stigma grows gradually and becomes bifid on the morning of the second day. The bifid condition of stigma is an indication of beginning of stigma receptivity and it remains receptive for two days. The stigmatic lobes recurve completely. A flower lasts for five days. The petals, stamens and stigma drop off while the calyx is persistent. The pollen production per anther is $1643.2 \pm 31.8$ (Range 1600-1690) and per flower is 6572.8. The pollen grains are light yellow, granular, tricolporate, reticulate, muri broad, flat, thick; lumina small irregularly shaped, colpi deeply intruding, and $33.2 \mu \mathrm{m}$ in size. The pollen-ovule ratio is 1,643.2:1. The flowers begin nectar secretion along with anther dehiscence. The nectar secretion occurs in minute amount which has accumulated at the ovary base and on the yellow part of petals and it glitters against sunlight. It is quite prominent during the entire period of stigma receptivity. A flower produces $0.4 \pm 0.08 \mu$ l (Range $0.3-0.5$ ) of nectar with a sugar concentration of $38 \%$. The sugar types included glucose and fructose and sucrose with the first as dominant. The results of breeding systems indicate that the flowers are self-compatible and self-pollinating. The fruit set is $12 \%$ in spontaneous autogamy, $33.33 \%$ in hand-pollinated autogamy, $40 \%$ in geitonogamy, $68 \%$ in xenogamy and $55 \%$ in open pollination.

The flowers were foraged consistently during day time from $07^{00}-17^{00} \mathrm{~h}$ by insects. The insects included Halictus sp., Chrysomya megacephala, Eristalinus arvorum, Rhyncomya sp., an unidentified fly, Polistes humilis and Catopsilia pyranthe. Individuals of each fly species were numerous on each tree. Bees were the exclusive pollen feeders. They also collected nectar throughout the flower life depending on the availability. All other insects collected nectar only. Each forager species made 11.5 to $17.5 \%$ of foraging visits (Fig. 8). 


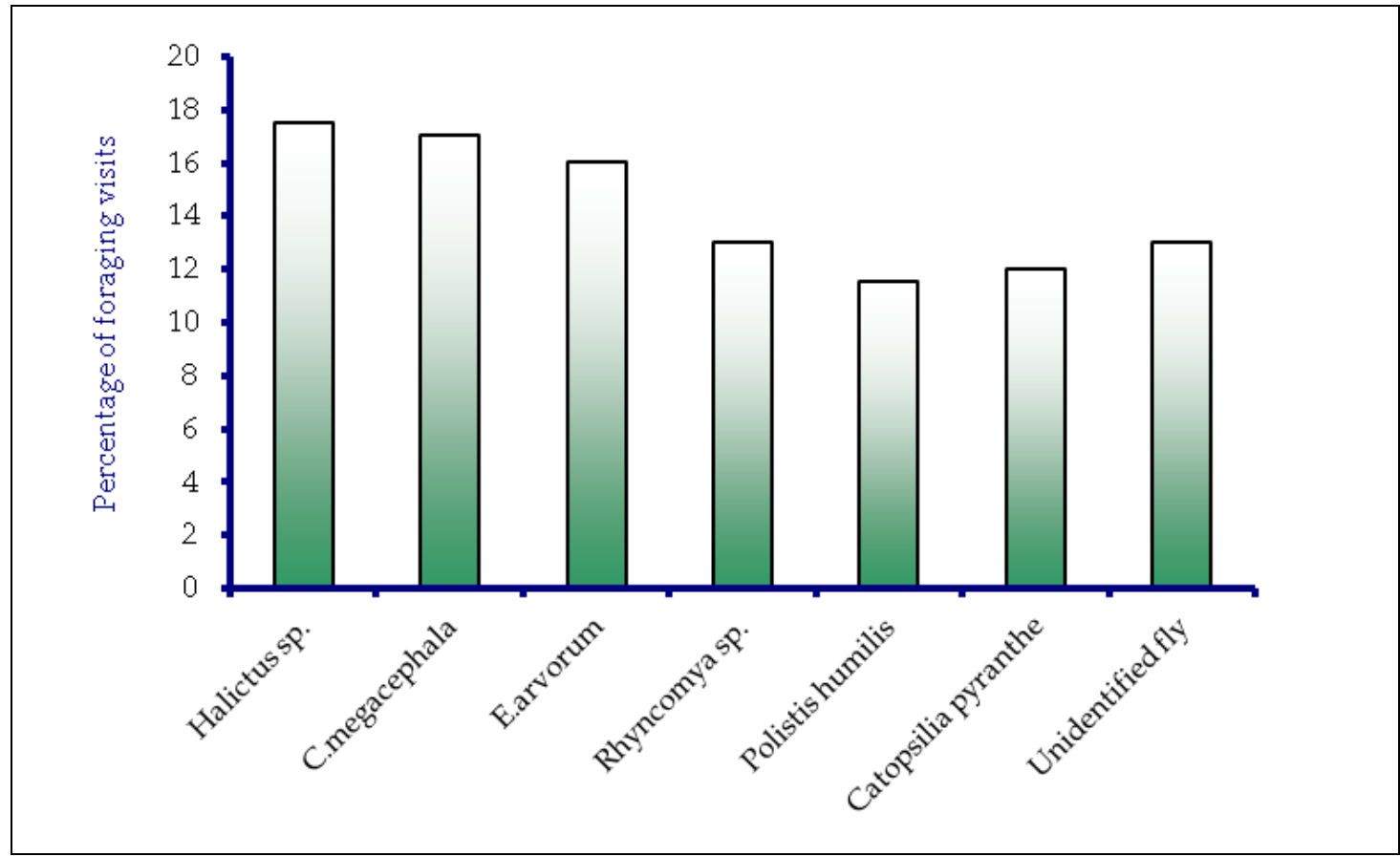

Figure 8: Percentage of foraging activity of insect organisms on Avicennia marina species.

All the insects probed the flowers in upright position to collect the forage. C. pyranthe landed on the petals, stretched its proboscis to collect nectar aliquots on the petals and at the flower base. In this process, all the insects invariably touched the anthers and the stigma; the ventral side of all insects was found with pollen. Further, the body washings of the all insect species revealed the presence of pollen; the average number of pollen grains per insect for each species varied from 63.1 to 227.4. As the nectar is secreted in minute amount, the insects made multiple visits to most of the flowers on a tree and moved frequently between trees to collect nectar. Such a foraging behaviour was considered to effect self- and crosspollination.

Pollinated and fertilized flowers initiate fruit development immediately and take about a month to produce mature fruits. In each fertilized fruit, only one ovule produces seed. Fruit is a one-seeded leathery grayish green capsule with persistent reddish brown calyx; 30-35 mm long, $25 \mathrm{~mm}$ wide, abruptly narrowed to a short beak and hairy throughout. Seed produces light green, hypocotyls, which completely occupies the fruit cavity. An inflorescence produces $6.88 \pm 2.96$ fruits (Range 3-20). The Rose-ringed Parakeet, Psittacula krameri was found to feed on the hypocotyl by damaging the fruit pericarp; the percentage of damaged fruits is $4 \%$. The fruit together with hypocotyl falls off the maternal parent, it settles in the substratum immediately at low tide period, it floats in water and disperses by tidal currents at high tide period until settled somewhere in the soil. The radicle side of hypocotyl penetrates the soil and produces root system while plumule side produces new leaves and subsequent aerial system. The fruit pericarp detaches and disintegrates when plumular leaves are produced. 
Avicennia officinalis (Avicenniaceae). It is a tall evergreen tree with irregular spreading branches giving crowned globose appearance. It grows to a height of more than 15$20 \mathrm{~m}$. The summer showers or early monsoon rains trigger flowering response. The rains vary in their occurrence and intensity even over a short distance; consequently the flowering period varies from place to place. The flowering season extends until August. The flowering density is almost uniform throughout the flowering season. Inflorescence is a terminal or axillary trichotomous panicle; each panicle produces $32 \pm 11$ flowers which anthese over a period of 16-25 days. Flowers are small, orange-yellow, ten mm long, ten mm wide, cup-shaped, have foetid smell, bisexual, slightly zygomorphic and oriented erect or partly horizontal. Calyx is shorter and has four ovate light green sepals with hairs on the outer surface; it is persistent. The corolla has four thick, light to orange yellow glabrous petals forming a short tube at the base; the petal margins are dull white. The adaxial petal is the broadest and shallowly bilobed. Stamens are four, epipetalous, three mm long and inserted basally on corolla. The anthers are basifixed, exserted, introrse and arranged alternate to petals. The ovary is very small (seven $\mathrm{mm}$ long), conspicuously hairy, bicarpellary syncarpous with four imperfect locules and each locule contains one pendulous ovule. It is terminated with a two mm long glabrous style tapered to the unequal bifid hairy stigma; both the style and stigma are light yellow throughout the flower life. The entire female structure is over-arched by stamens above. The style is bent, situated below the adaxial corolla lobe but not in the centre of the flower.

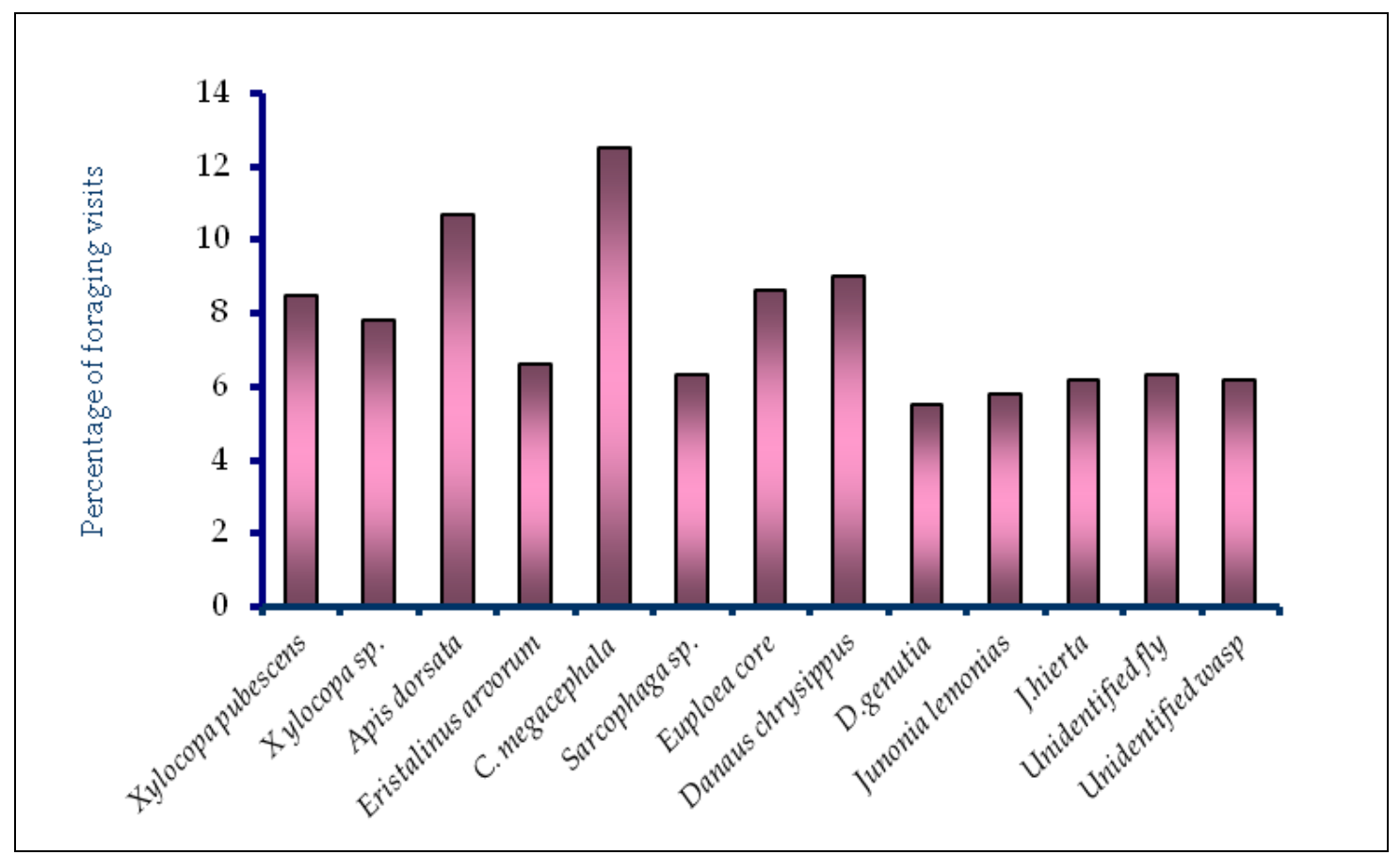

Figure 9: Percentage of foraging visits of insects on Avicennia officinalis.

The mature buds open throughout the day with most mature buds opening during $08^{00}$ $11^{00} \mathrm{~h}$. The petals slowly open and take two-three hours for complete opening to expose the stamens and stigma. The petals emit foetid smell at anthesis. The stamens bend inward overarching the stigma at anthesis and dehisce $0.5 \mathrm{~h}$ after anthesis. All the four anthers dehisce at the same time by longitudinal slits. Gradually, they become erect and bend backwards; to 
achieve this, they take three days. Then, the anthers became dark brown and petals turn light orange. Gradually, the bent stigma grows, becomes erect and is bifid on the morning of the third day. The bifid condition of stigma is an indication of beginning of stigma receptivity and it remains receptive until the fifth day. A flower lasts for seven days. The petals, stamens and stigma drop off while the calyx is persistent. The pollen production per anther is 2,444 \pm 202.4 (Range 2078-2604) and per flower is 8,837. The pollen grains are light yellow, granular, tricolporate, reticulate, muri broad, flat, thick; lumina small irregularly shaped, colpi deeply intruding, and $33.2 \mu \mathrm{m}$ in size. The pollen-ovule ratio is 2,209.3:1. The flowers begin nectar secretion along with anther dehiscence. The nectar secretion occurs in minute amount of the yellow part of petals and it glitters against sunlight. It is quite prominent during the entire period of stigma receptivity. A flower produces $0.65 \pm 0.09$ (Range $0.5-0.8) \mu 1$ of nectar with a sugar concentration of $39.75 \pm 1.89 \%$ (Range 36-43\%). The sugar types included sucrose, glucose and fructose with the first as dominant. The nectar amino acids included aspartic acid, cysteine, alanine, arginine, serine, cystine, proline, lysine, glycine, glutamic acid, threonine and histidine. All of these are prominent except lysine, glycine and proline. The results of breeding systems indicate that the flowers are self-compatible and self-pollinating. The fruit set is $21.42 \%$ in spontaneous autogamy, $42.85 \%$ in hand-pollinated autogamy, $63.33 \%$ in geitonogamy, $67.85 \%$ in xenogamy and $58.13 \%$ in open pollination.

The flowers were foraged consistently during day time from $07^{00}-17^{00} \mathrm{~h}$ by insects. The insects included Apis dorsata, Xylocopa pubescens, Xylocopa sp., Eristalinus arvorum, Chrysomya megacephala, Sarcophaga sp., Euploea core, Danaus chrysippus, D. genutia, Junonia lemonias, J. hierta, a fly and a wasp (unidentified). Individuals of each fly species were numerous at the flowers. A. dorsata was the only pollen feeder. It also collected nectar throughout the flower life depending on the availability. All other insects collected nectar only. Each forager species made 5.5 to $12.5 \%$ of foraging visits (Fig. 9). All the insects probed the flowers in upright position to collect the forage. In case of Xylocopa bees, they made audible buzzes while collecting nectar aliquots from the petals. The butterflies landed on the petals, stretched their proboscis to collect nectar aliquots on the petals. In this process, all the insects invariably touched the anthers and the stigma; the ventral side of all insects was found with pollen. Further, the body washings of the all insect species revealed the presence of pollen; the average number of pollen grains per insect for each species varied from 73 to 550.2. As the nectar is secreted in minute amount, the insects made multiple visits to most of the flowers on a tree and moved frequently between trees to collect nectar. Such a foraging behaviour was considered to effect self- and cross-pollination.

Pollinated and fertilized flowers initiate fruit development immediately and take about a month to produce mature fruits. In fertilized flowers, only one ovule produces seed. Fruit is a one-seeded leathery capsule with persistent reddish brown calyx; $30 \mathrm{~mm}$ long, $25 \mathrm{~mm}$ wide, abruptly narrowed to a short beak and hairy throughout. Seed produces light green, hypocotyl which completely occupies the fruit cavity. The fruit pericarp dehisces when the hypocotyl is ready for dispersal and when the latter is still on the mother tree. The entire dehisced fruit with hypocotyl inside falls off from the mother tree. The fruit pericarp together with hypocotyl settles in the substratum immediately at low tide period; it floats in water and disperses by tidal current at high tide period until settled in the soil. The radicle side of hypocotyl penetrates the soil and produces root system while plumule side produces new leaves and subsequent aerial system. The fruit pericarp detaches and disintegrates when plumular leaves are produced. 
Aegiceras corniculatum (Myrsinaceae). It is a small evergreen shrubby tree with spreading diffused branches, growing to a height of four-five $\mathrm{m}$. It flowers mainly from second week of February to second week of April; sporadic flowering occurs outside this period, especially during rainy season. The plant species such as Bruguiera gymnorrhiza (year-long bloomer), B. cylindrica (seasonal bloomer, September-March), Ceriops decandra (year-long bloomer) and Excoecaria agallocha (seasonal bloomer, July-August) occur in association with A. corniculatum. In A. corniculatum, an individual tree flowers for 22-25 days. Inflorescence is a simple umbel which arises in the shoot apex or in auxillary branches. An inflorescence produces $21.53 \pm 4.42$ flowers (Range 14-36). There is considerable synchrony of flower development in one umbel and in this state, the flowers appear in ball-like clusters. The umbels open in acropetal succession.

Flowers are pedicellate, pointed in bud condition, $17 \mathrm{~mm}$ long, seven mm wide, white, cup-shaped, fragrant, bisexual and zygomorphic. Sepals are five, small, five mm long, creamy white, twisted, free, coriaceous, round apex and persistent. Petals are five, free, five mm long, white, twisted to the left, slightly fused at base to form short tube of five-six mm length, mouth with a dense weft of hairs and capitate hairs at the base. Stamens are five, opposite to petals, epipetalous, adnate to the base of the corolla tube, filament creamy white, five mm long, base united to form a tube with a ring of internal and external hairs at the level of the mouth of the corolla tube. The anthers are bilobed, two mm long, inserted, sagittate, introrse and medifixed. Ovary is superior, conical, eight mm long, single-loculed with 35 ovules arranged on free central placentation in one chamber. Style is terminal, elongated, creamy white with dark brown dots, three mm long and extends beyond the mouth of the corolla tube. It has pedicellate glands at the base of the style and a nectariferous area at the base of the ovary, glabrous, soft, gradually tapering; stigma is apiculate.

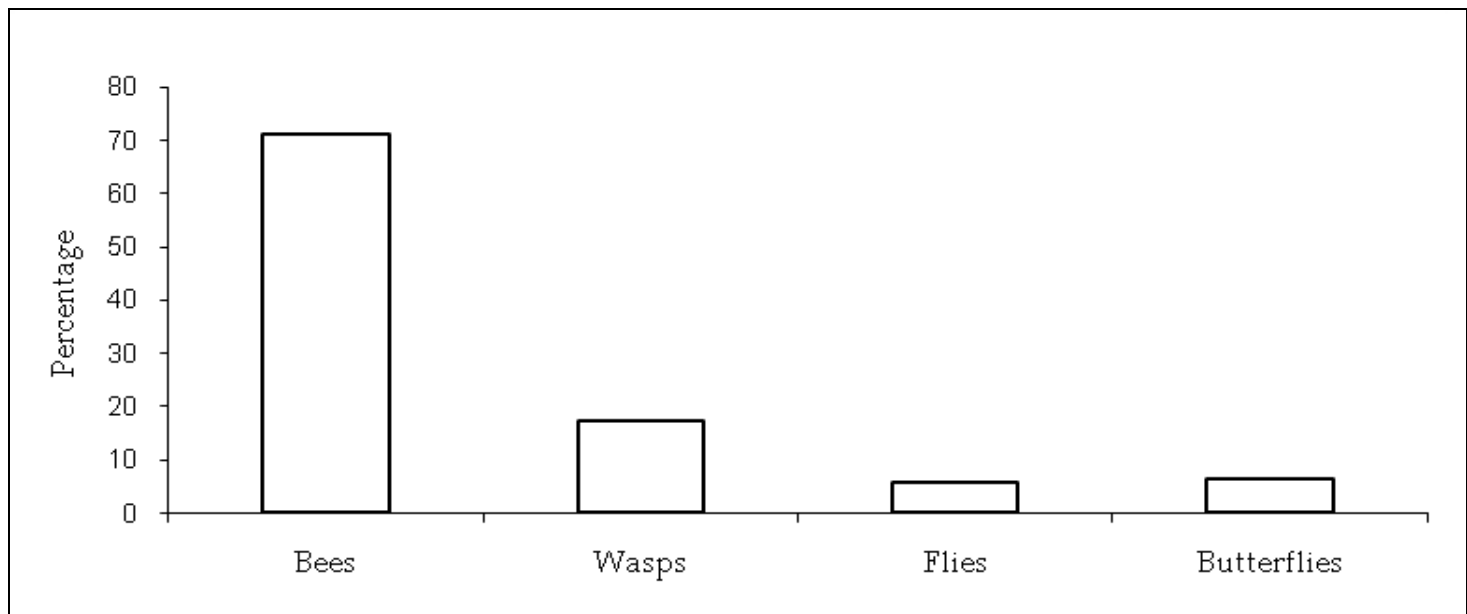

Figure 10: Percentage of foraging visits of insect categories on Aegiceras corniculatum.

The mature buds open at $06^{00} \mathrm{~h}$ by slightly unfolding the petals. Gradually, the erect petals take horizontal position and finally reflex backwards exposing stamens and the single style; this entire process takes place in a time span of three hours. The anthers enclose the style and stigma and are bend towards it; both parts attain almost the same height. Anther dehiscence occurs one hour after anthesis by longitudinal slits. The pollen output per anther is $15,221 \pm 1528.09$ (Range 12,864-18,336) and per flower is 76,105. Pollen grains are spheroidal, tricolporate with distinct annulus, dull white, exine smooth, thick and $33.2 \mu \mathrm{m}$ in 
size. The pollen-ovule ratio is 2,174:1. The pollen protein content per anther is $5.6 \mu \mathrm{g}$ and per flower is $28 \mu \mathrm{g}$. Pollen grains are viable for 3.5 days. The stigma attains receptivity almost at the time of anther dehiscence and continues up to the evening of the third day. A flower produces $4.08 \pm 0.6 \mu \mathrm{l}$ (Range 2.2-5) of nectar from the ring of tissue at the base of the ovary. The nectar sugar concentration is $36.46 \pm 3.7 \%$ (Range $32-40 \%$ ) and the common sugars include fructose and glucose with the former relatively more dominant. There is no significant correlation between nectar volume and sugar concentration $(\mathrm{r}=0.462$ at $\mathrm{p}>0.05$ significance level). The total sugar content in the nectar of a flower is $1.73 \pm 0.39 \mathrm{mg}$ (Range $0.76-2.63$ ). The nectar contains 13 amino acids which include tyrosine, glycine, proline, lysine, aspartic acid, glutamic acid, serine, cysteine, cystine, alanine, threonine, arginine and histidine. The flowers not pollinated fall off on the fifth day. In pollinated flowers, the petals and stamens drop off on the fourth day while the fruit is in a growing stage. The sepals and style are persistent, and remain on the plant even after the shedding of propagule. Floral bud abortion is $2 \%$. The results of breeding systems indicate that the flowers are self-compatible and selfpollinating. The fruit set is $7 \%$ in wind-pollinated flowers, $15.8 \%$ in spontaneous autogamy, $40.0 \%$ in insect-assisted pollination and $54.6 \%$ in open pollination. Fruit set per inflorescence in open pollination is $13.96 \pm 5.05$ (Range 5-24).

The flowers are unspecialized and the stamens and style become exposed when the petals reflex backward. They were foraged during day time from $06^{00}-17^{00} \mathrm{~h}$. The foragers included bees (Apis dorsata, A. cerana, A. florea, Amegilla sp., Nomia sp., Megachile sp., Xylocopa pubescens, $X$. latipes, Xylocopa sp.), wasps (Delta campaniforme, Polistes humilis and Odynerus sp.), a fly species, Chrysomya megacephala and butterflies (Catopsilia pomona, Euploea core and a Hesperiid). All these started their forage collection from $06^{00} \mathrm{~h}$ and continued until $17^{00} \mathrm{~h}$ with varying number of foraging visits at each hour. Bees collected both pollen and nectar throughout the day and accordingly the number of foraging visits were found to be nearly consistent. In the afternoon hours, bees were found to collect primarily pollen. Wasps, the fly and butterflies collected only nectar. They made a number of foraging visits during forenoon hours and gradually their visits were reduced towards the end of the day. Of the total number of foraging visits of insects, bees made $71 \%$, wasps $17.1 \%$, the fly $5.5 \%$ and butterflies 6.4\% (Fig. 10). Further, A. dorsata and Xylocopa species individually made higher percentage of foraging visits. All these insects while probing the flower for nectar and/or pollen invariably contacted the style, stigma and stamens. These insects while probing for nectar contacted the sex organs with their ventral and/or dorsal side. In case of butterflies, the proboscis usually contacted the sex organs; the head and wings rarely contacted the floral sex organs. Bees while collecting pollen always made contact with their ventral side. Body washings of insects revealed the presence of pollen grains; the mean number varied from 51.9 to 1552 . Bees were found to carry more number of pollen grains than all other categories of insects; the number of pollen grains found appeared to be related to the size of the bee species. Wasps with their smooth bodies were found to carry a small number of pollen grains. The fly was found to carry relatively more number of pollen grains than the wasps. Butterflies were found to transfer pollen grains principally through their proboscis; the proboscides were found with an average number of 93.3-117.3 pollen grains. Bees were also found to forage for pollen and nectar of Bruguiera gymnorrhiza occasionally. Nomia bees and Odynerus wasps also collected forage from Ceriops decandra occasionally. High winds prevailing in the plant area enabled the medifixed anthers with free movement to release light, dry and powdery pollen grains into the air easily. 
Pollinated and fertilized flowers initiate fruit development immediately and take 30-35 days to produce mature fruits. Of the 35 ovules, only one ovule enlarges and the others remain undeveloped. The developing ovule displaces the placenta laterally while the young seed elongates. Fruit is an elongated, one-seeded capsule, light green to pink, $65 \pm 5 \mathrm{~mm}$ long (Range 50-80), completely curved with pointed apex, persistent calyx and filled at maturity by the embryo with extended radicle and attached laterally by a long funicle-like structure. Seed coat is hard, brown, hairy with placental remains attached to mature seed coat and at the hypocotyl tip. Hypocotyl comes out of the seed coat but it does not pierce the pericarp. Mature fruit with well developed hypocotyl inside hangs downwards. They are water-buoyant and dispersed by tidal waters. After detachment from the mother plant, fruit pericarp dehisces longitudinally by absorbing water. The hypocotyl is not water-buoyant without fruit pericarp. In dehisced fruit, the green hypocotyl is exposed and produces a new plant when settled in a suitable substratum. The radicle side of hypocotyl penetrates the soil and produces root system while plumule side produces new leaves and subsequent aerial system.

Aegialitis rotundifolia (Plumbaginaceae). It is a soft-wooded evergreen shrub species, growing to three $\mathrm{m}$ height with a basally swollen fluted axis. It occurs in association with Ceriops decandra, C. tagal, Bruguiera gymnorrhiza and Excoecaria agallocha. Its leaves excrete salt which in turn gets crystallized on the leaf surface on sunny days. The flowering occurs from second week of February to third week of April. An individual tree flowers for 20-22 days. The flowers are produced in terminal, irregular one-sided cymes with pairs of opposite linear bracteoles. An inflorescence produces $6.2 \pm 1.6$ flowers (Range 4-10) over a period of six or seven days. Flowers are pedicellate, small, $18 \mathrm{~mm}$ long, $11 \mathrm{~mm}$ wide, white, cup-shaped, odourless, bisexual and zygomorphic. Sepals are five, small, nine mm long, green, united basally and free apically, glabrous, coriaceous, valvate and persistent. Petals are five, alternate to sepals, $12 \mathrm{~mm}$ long, white, herbaceous, free above with bluntly rounded lobes, fused basally to form a corolla tube of three mm long. Stamens are five, $12 \mathrm{~mm}$ long, free, inserted on the corolla tube alternately with the petals. The filaments are seven $\mathrm{mm}$ long, whitish, glabrous, slender, forming short hollow tube with a ring of internal and external hairs at the level of the mouth of the corolla tube. The anthers are bilobed, two $\mathrm{mm}$ long, inserted, sagittate, introrse and basifixed. The ovary is superior, oblong, onechambered with a single basally attached anatropous ovule. It has five grooves each extending into a lobe which in turn extending into a free style. The styles are five, free, white, each style ten $\mathrm{mm}$ long with an extended oblique peltate stigma initially facing inward and later facing outward.

The mature buds open at $07^{00}-09^{30} \mathrm{~h}$ by slightly unfolding a single petal first followed by the second petal and other petals within two hours. Petals reflex backward partially exposing the stamens and the styles. The styles and stigmas stand slightly below the height of the anthers, face inward at anthesis and diverge gradually moving away from the anthers but reaching closer to the petals. The anthers dehisce by longitudinal slits along with anthesis. The pollen output per anther is $288.6 \pm 40.27$ (Range 240-372) and per flower is 1443. Pollen grains are large, spheroidal, tricolporate characterized by prominent central wart-like sculptures, light yellow, exine rough, thick and $119.52 \pm 10.49 \mu \mathrm{m}$ in size. The pollen-ovule ratio is 1443:1. The pollen protein content per anther is $6.08 \mu \mathrm{g}$ and per flower is $30.04 \mu \mathrm{g}$. Pollen grains are viable for 2.5 days. The stigma attains receptivity two hours after anthesis and continues up to the evening of the third day. A flower produces $6.50 \pm 0.8$ (Range 5-7.8) $\mu \mathrm{l}$ of nectar at the flower base by the time of anthesis. The nectar sugar concentration is $46.2 \pm$ $5.4 \%$ (Range 36-53\%) and the common sugars include fructose and glucose which occur in 
almost equal amounts. There is no significant correlation between nectar volume and sugar concentration ( $\mathrm{r}=-0.386$ at $\mathrm{p}>0.05$ significance level). The total sugar content in the nectar of a flower is $3.60 \pm 0.49$ (Range 3.07-4.64) $\mathrm{mg}$. The nectar contains 16 amino acids which include tyrosine, glycine, lysine, aspartic acid, glutamic acid, serine, cysteine, cystine, alanine, threonine, arginine, phenylalanine, proline, tryptophan, valine and histidine. The corolla gradually turns from white to dark red from day one to day four. The dark red corolla together with stamens and styles remain in place for two to three weeks during which the calyx bulges due to growing fruit inside. The calyx is persistent and inseparable from fruit. The flowers not pollinated fall off on the fourth day. The results of breeding systems indicate that the flowers are self-compatible and self-pollinating. The fruit set is $9 \%$ in wind-pollinated flowers, $25 \%$ in spontaneous autogamy, $47 \%$ in insect-assisted pollination and $60 \%$ in open pollination. Fruit set per inflorescence in open pollination is $2.62 \pm 1.41$ (Range 1-7).

The flowers are unspecialized; the stamens and styles to become exposed when the petals reflex backward partially. They were foraged during day time from $07^{00}-16^{00} \mathrm{~h}$. The foragers were exclusively bees which included honey bees, Apis dorsata, A. cerana, A. florea and the Stingless bee, Ceratina simillima. All the bees collected pollen and nectar in the same and/or in a different foraging visit. Their foraging activity was primarily concentrated in the forenoon period and gradually decreased towards the end of the day. Of the total number of foraging visits of insects, $A$. dorsata and $A$. florea together made $64.5 \%$ while the other two bee species made the remaining percentage of visits (Fig. 11). All the bees while probing the flower for nectar and/or pollen invariably contacted the styles and stamens. The Apis bees were also found to forage for pollen and nectar of Bruguiera gymnorrhiza while $C$. simillima collected pollen and nectar of Ceriops decandra. High winds prevailing in the plant area enabled the anthers to release light, dry and granular pollen grains into the air easily.

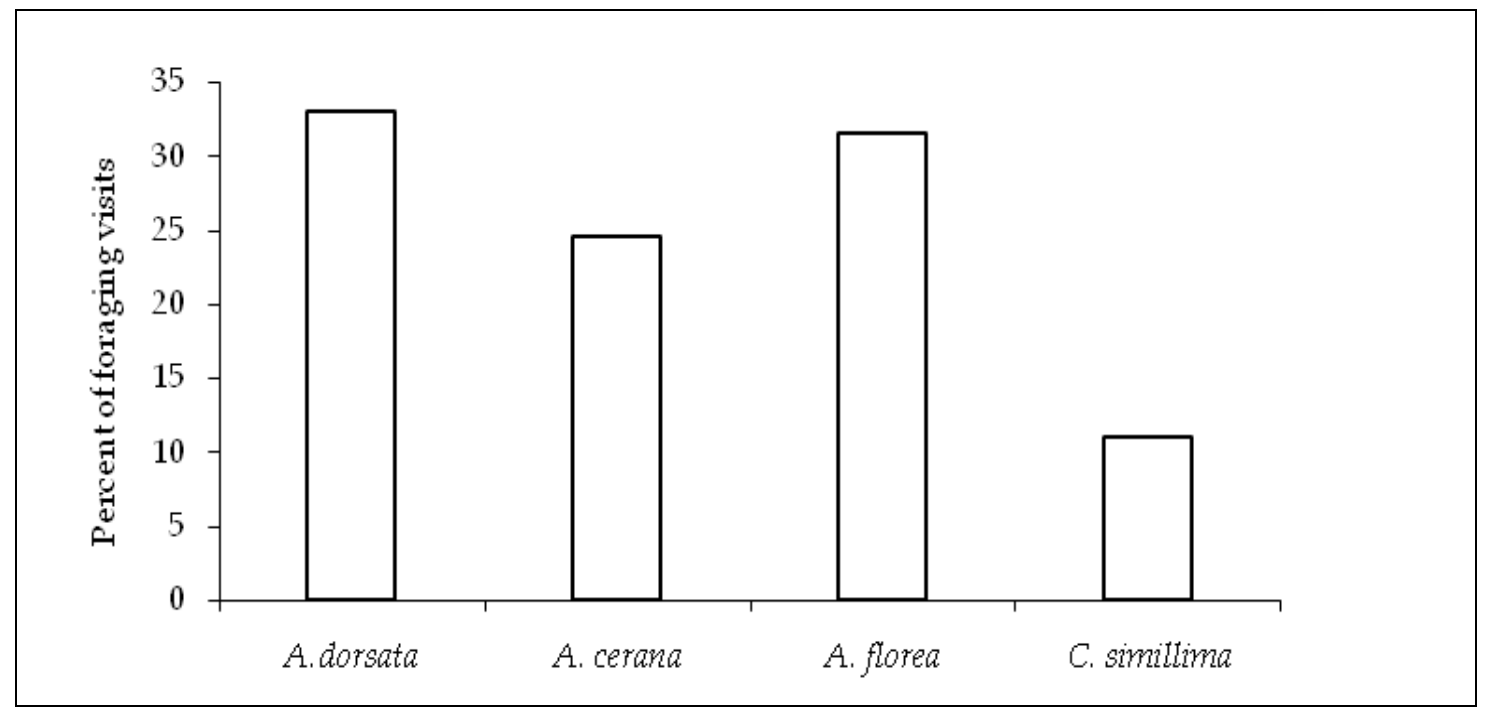

Figure 11: Percentage of foraging visits of bees on Aegialitis rotundifolia.

Pollinated and fertilized flowers initiate fruit development immediately and take 30-45 days to produce mature fruits. Fruit is an elongated, bluntly pointed one-seeded capsule, light green to brown, $72 \pm 4 \mathrm{~mm}$ (Range 65-83) long, enveloped basally by persistent calyx, funicular tube attached to seed and enlarging hypocotyl which protrudes from the seed coat but 
not the pericarp. Seed coat is hard, brown, embryo elongated with an extended hypocotyl. Mature fruit with well developed hypocotyl stands upright. Fruit pericarp is thin but thickened somewhat distally. It is water-buoyant and dispersed by tidal waters. It detaches along with the quadrangular calyx. The hypocotyls settle at the mother plant if the site is not inundated due to tidal water and float in tidal waters, especially during high tide periods. In fruits that float in tidal waters, the pericarp becomes soft and ruptures longitudinally to expose the hypocotyl to saline water. The hypocotyls devoid of fruit pericarp did not float while those with it floated. Such hypocotyls float until they find suitable substratum which is sticky and silty mud. The radicle side of hypocotyl penetrates the soil and produces root system while plumule side produces new leaves and subsequent aerial system. In the study area, very few propagules were found to settle, establish and produce new plants.

\section{DISCUSSION}

Ceriops tagal and Ceriops decandra. It is strictly a winter bloomer whereas its closely related species, $C$. decandra is a year-long bloomer with alternate flowering and fruiting phases (Solomon Raju et al., 2006). Aksornkoae et al. (1992) reported that the occurrence of the two species at the same site is rare; we also found similar situation at the Krishna mangrove forests. The distribution of $C$. tagal in this forest indicates that it has a distinct seaward zonation and prefers well drained high saline soils, suggesting that the species is a salt tolerant mangrove with the competitive ability to grow in highly saline and partly inundated locations (Aziz and Khan, 2001). The site is flooded with water only during high tides and is well drained during low tides indicating that $C$. tagal is a higher inter-tidal mangrove specialist and the plants occurring in such sites are inundated about twenty times a month (Duke et al., 1998). Further, in such sites, rainfalls make no differences and hence, the salt content of the soil remains high and approximately uniform throughout the year. Duke et al. (1998) reported that Excoecaria agallocha becomes more common in the absence of $C$. tagal in such sites. At the study site, a few trees of $C$. tagal occur with some naked habitat and E. agallocha grows here and there in its association. On the contrary, C. decandra is not a strict seaward mangrove plant and it occurs commonly even in areas of tidal zone far away from sea shore (Tomlinson, 1986). Field studies here showed that $C$. tagal is absent in Godavari mangrove forest, while a few trees still survive in Krishna mangrove forests. Therefore, $C$. tagal being a seaward mangrove, it is highly unsuccessful to establish a good population size, while its sister species, C. decandra, with flexibility to survive in tidal zones even far away from the seashore, is highly successful to build up its populations to the extent of becoming a common constituent of mangrove forests.

In C. tagal, the floral characteristics such as white flowers, strong fragrance, complex petal-stamen configuration and production of moderate amount of nectar suggest an elaborate and specialized floral mechanism. The petals require an external delicate touch for the explosive release of stamens. The helically coiled hairs at the lower margins of the petals help to propagate explosive pollen release effectively (Juncosa and Tomlinson, 1987). The petal clavate appendages of petals in $C$. tagal lack hydathodes and abundant xylem which are characteristically present and have a role in flower function under extreme water pressure deficits during the day in C. decandra (Juncosa and Tomlinson, 1987). Such a state may make appendages very light and provide necessary trigger for petal explosion by delicate touch by the forager in C. tagal. Explosive pollination mechanism has also been reported in Bruguiera species for which the flower tripping agents are birds and butterflies (Tomlinson et al., 1979; Ge et al., 2003). 
Tomlinson (1986) reported night-flying insects, especially moths, as probable pollinators. Meeuse and Morris (1984) described the characteristics of moth flowers which include flower opening in the evening, display of overwhelming fragrance at that time, light flower colour, absence of landing platform, fringed petals for guidance, visual and olfactory nectar-guides, long and narrow corolla tube, abundance of nectar and short-tongued visitors. Baker and Baker (1983) reported that hawk moth flowers produce sucrose-rich or dominant nectar with low sugar concentration. Cruden et al. (1983) reported that small moth flowers produce relatively small volume of nectar with small amount of sugar. They also stated that moth flowers initiate nectar secretion one-three hours or even ten or more hours prior to the activity period of moths. In the $C$. tagal, nectar guides and tubular corolla are lacking, the nectar secretion begins an hour after anthesis; it is in moderate volume, hexose-rich with high sugar concentration. These characters together with the shallow nature of flowers are suitable for foraging by short-tongued bees and flies (Baker and Baker, 1983; Cruden et al., 1983). In this study, there was no foraging activity of hawk moths or settling moths at the flowers after anthesis til late evening (up to $22^{00} \mathrm{~h}$ ) and the absence of moths could be due to nonavailability of nectar at anthesis and reduced opportunities for food and breeding opportunities in harsh mangrove habitats. C. tagal with a few trees and a few numbers of flowers per unit of time per tree does not constitute a potential nectar station for moths. Further, adult moths do not survive for longer periods and in particular, hawk moths may survive for a period exceeding a month (Opler, 1983). Within that life span, the availability of nectar in the habitat is crucial and since $C$. tagal is unable to attract and supply its nectar requirements, the moths might have disappeared or migrated to other reliable food-rich habitats. Apis bees and Chrysomya flies make up day-time foragers for $C$. tagal. With a small number of trees and again each tree with a small number of flowers per day, C. tagal is not a potential pollen and nectar source for honey bees. Yao et al. (2006) also reported that this plant species is a minor pollen and nectar source for honey bees. In the study site, Aegiceras and Bruguiera flowers attract honey bees and the latter were found concentrating on these species. Chrysomya flies frequent the flowers of $C$. tagal daily effecting pollination but they have limited pollen transport capacity; this however, is compensated by their numbers and could bring about substantial geitonogamy and xenogamy (Faegri and van der Pijl, 1979). The petal colour change may act as a nectar guide for the flies to visit the flowers for several days. The close proximity between trees of $C$. tagal at the study site also facilitates xenogamy. The fly is present throughout the year unlike periodic bees and moths; but its presence depends on local opportunities for breeding sites (Faegri and van der Pijl, 1979). The butterfly is an occasional forager and has no role in pollination. Our observations suggest that Chrysomya is the primary and consistent pollinator, while honey bees are secondary and occasional pollinators. Petal explosion also occurs sporadically in nature due to wind action and this is evident in bagging experiment in which there is a negligible fruit set and also in natural conditions to some extent. The role of wind in tripping explosive pollination has also been reported in Hyptis suaveolens (Lamiaceae) (Solomon Raju, 1989) and Shorea robusta (Dipterocarpaceae) (Aluri et al., 2004). Therefore, petal explosion and subsequent pollination events are primarily vector-dependent and inadequate numbers or non-availability of pollinators are bound to result in reduced or no fruit set in C. tagal.

Less is known about the importance of amino acids in floral nectars to foragers. Amino acids are the second most abundant class of the compounds after sugars to be found in nectar (Gardener and Gillman, 2002). Their concentrations in nectars are considerably lower 
than sugar concentrations. But even the slightest concentrations are important nutritionally and also contribute to the "taste" of the nectar (Baker and Baker, 1983). Honey bees respond to differences in amino acid concentration and detect amino acids. They prefer certain amino acids and their presence makes nectar more attractive (Dress et al., 1997). Tyrosine is not an essential amino acid, but may be important in the formation of sclerotin (Gardener and Gillman, 2002). Phenylalanine is a precursor of specific honey aroma component, phenylethanol (Thawley, 1969), iso-leucine is required for rapid breeding (Slansky and Feeny, 1977). Flies also prefer amino acids in nectar. In the flies, Boettcherisca peregrine and Phormia regina, proline stimulates salt receptor cells, methionine and valine stimulate sugar receptors, methionine also elicits a feeding response from flies and glycine and serine invoke an extension of the proboscis (Shiraishi and Kuwabara, 1970; Goldrich, 1973). C. tagal flowers with a mix of floral characteristics of moth, bee and fly flowers contain conventional protein building amino acids such as tyrosine, glycine, methionine, proline, lysine, aspartic acid, glutamic acid, serine, cysteine, alanine, threonine and arginine but are devoid of other proteinbuilding amino acids such as phenylalanine, valine, leucine, iso-leucine, tryptophan and histidine. The nectar provides an instant supply of methionine, lysine and arginine for honey bees and flies; moths if occur in the habitat also make use of this nectar for protein building. The presence of several amino acids in this nectar source stimulates feeding and may also be an important source for flower foragers.

C. decandra as a common species in most of the regions and its distribution range may have achieved distinct out-crossing rates and accordingly, it has been reported to be an outcrosser (Solomon Raju et al., 2006). On the contrary, C. tagal with a small number of individuals at the study site can produce offspring with mixed mating system only if it fails to attract potential and adequate pollinators. In line with this, we have found that it possesses such a system to produce fruit set even through autogamy. But, autogamy is negligible as realized in bagging experiment. In Kandelia candel and also in a crypto-viviparous species, Avicennia marina, negligible self-pollination has been reported in bagging experiments (Sun et al., 1998; Clarke and Myerscough, 1991). The fruit set in C. tagal is through geitonogamy and xenogamy. The long flower life and stigma receptivity and high pollen-ovule ratio (Cruden, 1977) indicate that the plant is primarily out-crossing. However, the close proximity of the existing trees at the study site in the course of time could bring about genetic uniformity and if this happens, then the survival of this species becomes doubtful.

In $C$. decandra, the floral characteristics such as small white flowers lacking fragrance, simple stamen-petal configuration, short, thick filaments and production of trace amount of nectar suggest a simple floral mechanism. Juncosa and Tomlinson (1987) stated that the short basal hairs of petal edges have no evident function in $C$. decandra, but these hairs are well developed and help to propagate explosive pollen release effectively in fragrant flowers of C. tagal, in which the petal-stamen configuration is elaborate and specialized. Further, these authors reported that petal clavate appendages in C. decandra have abundant xylem elements with a significant reservoir of water and hydathodes at or near the termini; they have significance in flower function under extreme water pressure deficits during the day in mangrove swamps. Abundant xylem is absent in petal appendages in C. tagal and K. candel, which are pollinated at night or early in the morning (Juncosa and Tomlinson, 1987). Therefore, the abundant xylem and hydathodes and their function in petal appendages of $C$. decandra suggest that the latter is adapted for pollination during the day. Tomlinson (1986) suggested that wasps and flies are suitable for pollination in C. decandra. Juncosa and Tomlinson (1987) noted that trigonid bees and small insects visit $C$. decandra flowers. In the present study, bees while collecting pollen and nectar and wasps while collecting nectar 
pollinate C. decandra flowers consistently. Female bees of Nomia and worker bees of Trigona collect pollen voraciously for brood provisioning. Female wasps collect nectar after mating for the maturation of the eggs. The plant produces a small number of flowers daily and accordingly, the pollen and nectar available is also in small quantities. Further, the anthesis process is gradual and the accumulation of new flowers with pollen and nectar begins to appear from late morning. As a consequence, bees and wasps also delay their foraging activity and appear from late morning onwards and stop foraging in the early evening. As flower number and floral rewards are small at the plant level, both bees and wasps fly between individuals of $C$. decandra in quest of more forage and this foraging behaviour brings about cross-pollination. Hand-pollination tests showed that it is an obligate outcrosser. The protandry, long period of stigma receptivity and long flower life substantiate this; pollination by bees and wasps favours outcrossing (Tomlinson, 1986). The pollen recovered from the body washings of these foragers suggests that they effect pollination. Earlier reports on bees, flies, wasps or even other insects as pollinators (Tomlinson, 1986; Juncosa and Tomlinson, 1987 ) and the present study on bees and wasps as pollinators suggest that $C$. decandra is strictly entomophilous and utilizes different locally available insects as pollinators. The commonness of $C$. decandra at Coringa mangrove forest provides ample opportunities for effective outcrossing and the genetic variation thus achieved would permit the species to survive well in the harsh mangrove environment.

In C. tagal, the number of fruits per inflorescence varies from one to five, but one- and two-fruited inflorescences are most common. The fruited flowers produce only one seed against the actual number of six ovules as in C. decandra and all other viviparous species of Rhizophoraceae. This characteristic may permit these plants to save resources and use them to produce one-seeded viable fruits. Despite this effort by C. tagal, a few propagules lack green pigment and becoming entirely yellowish or yellowish on one side and purplish on another side. Such hypocotyls have been referred to as "albino" forms which also occur in C. decandra and Bruguiera gymnorrhiza (Solomon Raju et al., 2006; Allen and Duke, 2006). These propagules are non-viable, cannot photosynthesize and die after depleting reserves if settled in the habitat. The propagules that are green first and brownish purple later are healthy and grow to their actual size. The length of hypocotyls in $C$. tagal is almost double the length of hypocotyls in C. decandra. Both the species of Ceriops show a short period of attachment to the maternal plant (Solomon Raju et al., 2006) and this characteristic is not in agreement with the report of Bhosale and Mulik (1991) that the hypocotyls of true viviparous mangrove species remain attached to the mother plant for a full year. The hypocotyl grows upward in $C$. decandra in which flowers are sessile (Solomon Raju et al., 2006), while in C. tagal, it grows downward which seems to be because of stalked flowers and more weight of the hypocotyls. This is an important field characteristic feature to distinguish C. tagal from C. decandra. The downwardly hanging hypocotyl is also a characteristic of Bruguiera, Rhizophora and Kandelia species. In C. tagal, the cotyledonary yellow cylindrical collar emerges from the fruit about ten days prior to the detachment of the hypocotyl while this structure is entirely absent in $C$. decandra (Solomon Raju et al., 2006). The cotyledonary collar is a characteristic also in Rhizophora in which it is reddish brown and in Kandelia in which it is yellow and the hypocotyl is about double the length of $C$. tagal (Aksornkoae et al., 1992).

Fruit in C. tagal grows continuously and the seed also has no dormancy like in other mangrove species of Rhizophoraceae (Farnsworth and Farrant, 1998). This form of fruit growth and seed germination leading to the formation of hypocotyl while still attached to the 
mother plant represents "vivipary", the opposite of "ovipary" in which seed dormancy is the rule. The viviparous condition has been considered as an evolutionary loss of seed dormancy (Farnsworth and Farrant, 1997), however, it is an adaptive feature for the plant to overcome the harsh tidal environment for seedling establishment in the parental sites but it is not considered adaptive for dispersal either in time or space (Sun et al., 1998). The other adaptive values of vivipary include facilitation of early rooting (MacNae, 1968), buoyancy during sea dispersal (Rabinowitz, 1978), transfer of maternal nutrients to the hypocotyls (Pannier and Pannier, 1975), maintenance of embryonic osmotic equilibrium and establishment in coarse grained environments. On the other hand, vivipary incurs maternal costs to supply water and necessary nutrients. Numerous attached seedlings may constitute a substantial carbon sink to the maternal plant, a concentrated apparent resource for herbivores (Farnsworth and Farrant, 1998). C. tagal at the study site was found to produce 20 to 60 hypocotyls per tree and it is not known whether this small number could attract herbivores.

Kairo et al. (2001) reported that viviparous mangrove species use self-planting or stranding strategy for establishment depending on forest conditions tide and stability of the soils. The self-planting strategy dominates in undisturbed mangrove forests but stranding strategy is dominant in exploited and open or naked forests (Dahdouh-Guebas et al., 1998). C tagal with epigeal seed germination, elongated and pointed hypocotyls with straight curvature (Clarke et al., 2001) fall freely from the mother plant and plant themselves into the mud at the same site during low tide period. The hypocotyls if fallen during high tides float to another site for settlement. But, our field studies do not show settlement of hypocotyls away from the mother plants suggesting that $C$. tagal uses self-planting strategy only. This is further substantiated by McGuinness (1997), who also reported that the hypocotyls of C. tagal in Northern Australia dispersed to very short distances; only 9\% moved more than three $\mathrm{m}$ from the parent tree. He also mentioned that within that short distances, a high percentage of them were either damaged or eaten by animals. C. tagal at the study site may also be experiencing the damage or consumption by animals, especially crabs as the latter have been reported to show high predation on hypocotyls in high inter-tidal areas (Duke et al., 1998). Some of the fallen hypocotyls settled at the mother plants showed signs of weathering. Therefore, the study suggests that $C$. tagal though occurring in undisturbed and human-free site, is almost unable to add new plants and the presence of only a few individuals at the site attests this contention. The work reported in this paper is important for initiating studies on the genetic structure of $C$. tagal population. The genetic marker analysis helps to understand the variability within and between populations. Introduction of $C$. tagal from the mangrove forests of the Sundarbans, Andaman and Nicobar islands to this site would help to enhance gene flow in order to maintain the gene diversity and expansion of population size of $C$. tagal in Krishna mangrove forests.

The pollinated flowers initiate fruit growth and development immediately and produce mature fruits in about two months. Fruits are light green, ovoid, conical and blunt apically. They are distinct with five-lobed persistent calyx and produce only a single seed. The seed has no dormancy and it immediately produces spindle-shaped hypocotyls within three months, while still attached to the maternal parent. Then, it detaches from the residual fruit. The hypocotyl is slender, green, clearly ribbed, angular, sulcate, $15 \mathrm{~cm}$ long and broadened at the lower end. The short period of hypocotyl attachment to the maternal parent is a characteristic of cryptoviviparous species (Bhosale and Mulik, 1991). However, C. tagal shows this characteristic, being a true viviparous species (Selvam and Karunagaran, 2004). Further, the hypocotyl in $C$. decandra grows upright and is an important characteristic to distinguish it from C. tagal in which the hypocotyl grows downward (Kathiresan and Rajendran, 2003). In C. decandra, the hypocotyl is characteristically green and seems to have the potential to 
photosynthesize actively with water and necessary nutrients drawn from the parent tree. Viviparous reproduction allows hypocotyls to develop some salinity tolerance before being released from the parent tree. It provides a store of nutrients before the hypocotyls fall-off from the plant and helps in quick rooting in the muddy environment. The hypocotyl characteristics also help to develop buoyancy for distribution of the seedlings and structural stability to protect seedling from damage (Kathiresan, 2003). Therefore, vivipary could be an adaptive feature of the plant to overcome the harsh tidal environment for seedling establishment, especially in the parental sites. The small upright hypocotyls, when detached from the mother plant, float in water and settle at different places depending on the direction and extent of movement of tidal water. Such dispersal characterizes "Stranding Strategy".

Pollinator species of $C$. tagal and $C$. decandra need a special mentioning here. The fly pollinators have rich sources of breeding and feeding materials in the forests, but the breeding materials are subject to flooding during high tide periods and during rainy season. Bees and wasps use above ground plant materials such as live/dead branches/wood. But, these materials are usually collected by local people for use as fuel wood. The forage collection from plants occurring in windy areas is a difficult task for them and hence these foragers tend to collect the forage from the plants occurring landward. These foragers have no difficulty to collect forage from C. decandra as the latter is distributed principally landward. In case of C. tagal, it occurs seaward where wind blows at high speed which usually prevents or minimizes the foraging activity of honeybees. In consequence, the bees tend to collect the forage from the flowers covered by the branches and foliage where there is reduced wind speed.

The importance of bark of $C$. decandra in dyeing the cotton and fishing nets here is driving the fishermen to cut down trees indiscriminately and the tree cutting rate is further driven by the trade concept in some fishermen. Most of the areas where $C$. decandra occurs have been partly cleared for its bark and wood. The cleared areas show the stumps or the basal part of the cut trees and these areas are gradually being invaded by the oviparous weed species, Excoecaria agallocha. Further, some such areas are being used as cattle shelters by some villagers. Therefore, such areas cleared of $C$. decandra trees and the still existing stretches of C. decandra are an important consideration for the concerned forest authorities with regard to conservation, management and artificial regeneration of this species in naked and semi-naked mangrove habitats in order to provide a continuous supply of bark tannin for fishermen for treating their cotton fishing nets.

Rhizophora apiculata and Rhizophora mucronata are polyhaline, evergreen true viviparous tree species. The former species blooms throughout the year, but shows profuse flowering for two months during August-September while the latter species flowers for about six months with profuse to sparse flowering during August-September. Mulik and Bhosale (1989) reported that $R$. mucronata flowers throughout the year with intense flowering during September-November. The flowers are sessile and borne in pairs below the leafy cluster in $R$. apiculata, while they are pedicellate and borne in four-flowered cymes within the leafy cluster in $R$. mucronata. With foliage background, the flowers of $R$. mucronata are also quite prominent and may be more attractive to flower foragers when compared to those of $R$. apiculata. In the latter species, bee foraging activity has been found to be consistent during profuse flowering period than at other times of the year. This suggests that greater floral displays during profuse flowering period have an important role in attracting bee pollinators. The year-long flowering allows the plant to set fruit continuously and this may be a fail-safe strategy against pollination limitation and propagule predation. 
In both the species of Rhizophora, the flowers exhibit certain adaptations for anemophily. The flowers are pendulous, point downward at maturity and situated below or within the leafy crown; this floral orientation is important to minimize interference of foliage for effective pollen dispersal by wind. The sepals diverge least, while the petals are glabrous, do not recurve or retain pollen grains in $R$. apiculata. But, in $R$. mucronata and in all other Rhizophora species, the petals are equipped with marginal hairs which have been shown to be promoters of anemophily by their hygroscopic movements (Tomlinson, 1986). Late morning anthesis, high pollen/ovule ratio, light powdery pollen, absence of an attractive colour and odour, absence of abundant pollinators and the presence of traces or minute quantity of nectar are some important characteristics for anemophily in the genus Rhizophora in general (Tomlinson, 1986) and in the studied species of Rhizophora in particular. Further, anther dehiscence and pollen release occur in mature bud in both Rhizophora species. In both, the late morning anthesis is another important characteristic for the effective dispersal of dry powdery pollen grains from the already dehiscent anthers due to moderate levels of temperature and humidity present at that time. The anthesis period noted in this study for $R$. mucronata does not agree with the report by Kondo et al. (1987) that the anthesis occurs in the afternoon from $15^{00}$ to $17^{00} \mathrm{~h}$. These two plant species occur as pure stands mostly and are located in a windy environment along the creeks. This form of distribution may facilitate effective dispersal of pollen between individual trees and receptive sites of flowers receive wind-borne pollen. Kondo et al. (1987) reported that the pollen grains also have evolved characteristics for anemophily. Tomlinson et al. (1979) also experimentally proved that wind-borne pollen is abundant and hence anemophily is most efficient in such pure stands of other Rhizophora species. Although both $R$. apiculata and $R$. mucronata have several adaptations for anemophily, their stigma is not elaborated in the manner usual for wind-pollinated species to capture wind-borne pollen. Similar structure of the stigma has been reported in all other Rhizophora species (Tomlinson, 1986). The absence of marginal hairs on petals, lack of elaboration of stigma, absence of odour and presence of traces or minute quantity of nectar seem to be vestigial characteristics of entomophily. Kress (1974) also related these characteristics to entomophily in $R$. mangle and $R$. stylosa.

The flowers of $R$. apiculata attract the bees such as Nomia, Trigona and Halictus, while those of $R$. mucronata attract the bees such as Nomia, Trigona, Halictus, Ceratina and Xylocopa, and a moth species. Kondo et al. (1987) reported that $R$. mucronata is anemophilous, but is also pollinated by small insects like Camponotus sp., Onychostylus pallidiolus and a Collembola. In both the plant species, pollen is the principal reward since it is produced in huge amount. Further, the flowers are nectariferous but the nectar is secreted in traces or in minute quantity and hence has little importance for the foragers. The pollen and/or nectar feeding behaviour of these bees and the moth would contribute to pollination. But, their pollen feeding activity may considerably reduce the availability of airborne pollen and hence may affect the efficiency of anemophily. The copious production of pollen at flower level may compensate to some extent the pollen loss caused by pollen collecting bees. Further, thrips have been found in the floral buds of both $R$. apiculata and $R$. mucronata. Their presence in the buds indicates that egg deposition by female thrips takes place prior to bud formation; the eggs hatch, produce larvae or adult thrips by the time the buds mature. These thrips represent the suborder Terebrantia of the order Thysanoptera. The females of this group of thrips have an ovipositor with which they cut slits into plant tissue in order to insert their eggs, one egg per slit. With this ability, these thrips raise their offspring in floral buds. They are short-distance flyers, but windy areas extend their travel distance to a great extent. They feed on both nectar 
and pollen and in so doing contribute to both self- and cross-pollination, but the latter mode is more effective in areas where pure stands of Rhizophora species occur. The study suggests that the pollination mechanism in the studied Rhizophora species is originally entomophilous and is now being transformed to anemophily. This transitional stage of pollination mechanism is advantageous for these plant species to utilize both wind and insects as pollinating agents for the success of sexual reproduction. Tomlinson (1986) stated that animal pollination predominates in mangrove communities and in such a situation anemophily enables these species to escape the competition for insect pollinators and to set fruit in the total absence of insect pollinators.

Tomlinson (1986) reported that Rhizophora exhibits weak protandry and is selfcompatible. He found that the isolated greenhouse plants set fruit. He has not mentioned what species of this genus are weakly protandrous and self-compatible. Coupland et al. (2006) reported that Rhizophora species show low rates of fruit set due to lack of autogamy. Ghosh et al. (2008) mentioned that a distinct trend for self-incompatibility exists in Rhizophora. In this study, $R$. apiculata and $R$. mucronata show anther dehiscence in mature bud and commencement of stigma receptivity soon after anthesis, suggesting that they are weakly protandrous. Tomlinson et al. (1979) reported that in these species, the petals and stamens fall off the flower on the day of anthesis leaving the central stigma alone in the empty flower. These authors also stated the stigma lacks any secretion or divergence of its two lobes. Kondo et al. (1987) reported that the stigma is two-lobed; each tip contains small papilla and secretes mucilage. In this study, it is found that the stigmatic lobes diverge soon after anthesis and since then it is in receptive stage to receive pollen. The stigmatic lobes are mucilaginous and have minute papilla, which may aid in capturing and retaining pollen readily.

Tomlinson et al. (1979) reported that in Rhizophora stylosa, an individual flower is generally incapable of self-pollination. Hand-pollination results suggest that $R$. apiculata and $R$. mucronata are capable of self-pollination either by gravitational fall of pollen or by wind driven pollen fall on the stigma. Further, these plants set fruit through allogamy, autogamy and geitonogamy (Kondo et al., 1987). The significantly low fruit set evidenced in openpollinations is attributable to the intense pollen feeding activity of bees and also to the wastage of pollen due to wind activity. Coupland et al. (2006) also reported low fruit set to the extent of $13 \%$ in open-pollinations. The ability to set fruit through self- and cross-pollination is the characteristic of pioneering species in mangrove communities. $R$. apiculata and $R$. mucronata with this ability may become established as isolated individuals in new environments remote from parental source.

Like in Bruguiera cylindrica, the flowers are four-ovuled in both Rhizophora species, but only one ovule develops into mature seed in fertilized and fruited flowers. The production of one-seeded fruits may be due to maternal resource constraint or maternal regulation of seed set. Fruits mature within four to six weeks and are not enclosed by the persistent and expanded calyx at any stage. The calyx therefore seems to have no role in protecting the fruit. As the fruit is thick with hard pericarp, it does not require protection from the calyx. In both $R$. apiculata and $R$. mucronata, the single seed formed in the fruit is not dormant and germinates immediately to produce a cylindrical hypocotyls or seedling, while still on the maternal parent. The hypocotyl emerges out of seed and fruit pericarp and remains naked until it is detached from the maternal parent. This is a characteristic of "true viviparous" species (Tomlinson, 1986). While still attached to the 
maternal parent, the seedling develops chlorophyll and actively photosynthesizes; the parent tree supplies the water and necessary nutrients (Selvam and Karunagaran, 2004). The seedling hangs downward and detaches from the residual fruit at the collar end, leaving behind its cotyledons, and falls from the maternal parent. Christensen and WiumAndersen (1977) speculated that in $R$. apiculata, the development from visible flower buds to mature propagules lasts about two years while Muniyandi (1986) reported that the propagule takes eight months to grow to full length after fertilization. But, in this study, it is found that this species produces mature seedlings from flower buds in a time span of about four months only. Muniyandi (1986) say that the seedlings of $R$. mucronata take 16 months to grow to full length after fertilization in $R$. mucronata. But, in this study, it is found that this species produces mature seedlings from flower buds in a time span of about four months only.

The fallen seedlings of $R$. apiculata and $R$. mucronata plant themselves into the mud in the vicinity of the maternal parent or are stranded and planted away from maternal parent. In the latter case, the seedlings sink after some period of dispersal and exhibit growth under water (Rabinowitz, 1978). The study shows that the seedlings disperse through self-planting and stranding strategies. Although dispersal distances have not been measured in this study, the available information shows that most viviparous seedlings do not disperse more than one $\mathrm{km}$ from their point of origin (Clarke, 1993), and in certain instances, as little as $65 \mathrm{~m}$ (Chan and Husin, 1985) or even three m (McGuinness, 1997). Davis (1940) found that Rhizophora mangle propagules carried by ocean currents could disperse at least $100 \mathrm{~km}$. Smith (1987) reported seedling predation prior to and after detachment from the maternal parent in $R$. apiculata and $R$. mucronata. Monkeys and insects attack seedlings prior to their detachment, while crabs attack seedlings when they later fall in the mud or tidal water. Monkeys, insects and crabs collectively contribute to more than $83 \%$ of seedling predation. Bosire et al. (2005) reported that seedling predation is a mechanism to regulate individual species colonization, but in case of $R$. mucronata, the seedling predation is the least since they are very large and are not preferred by crabs. In this study, there is no seedling predation prior to detachment from the maternal parent in both the species of Rhizophora. Seedling predation by crabs may be there since different species of crabs have been found. The locals use crabs as a source of food and livelihood.

Bruguiera gymnorrhiza and Bruguiera cylindrica. Both the species of Bruguiera are polyhaline, evergreen true viviparous tree species. B. gymnorrhiza is a year-long bloomer with concentrated flowering during April-June, while B. cylindrica shows flowering during September-March during which flowering level is almost uniform. On B. gymnorrhiza, pollinator activity is consistently intense during concentrated flowering period, while it is sporadic at other times of the year. On the contrary, pollinator activity is not consistent and also not intense at any point of time on B. cylindrica. This finding stated that pollinators preferentially visit plants with greater floral display. Therefore, fruit set is largely a function of pollinator activity during concentrated flowering period in $B$. gymnorrhiza. However, the characteristic of year-long or extended flowering in these two tree species is an important adaptation for additional fruit set; this characteristic would enable them to compensate the low fruit set rate which may result from pollinator limitation and also to compensate the loss of seedlings due to predation. 
Tomlinson (1986) reported that B. gymnorrhiza represents the large, solitary-flowered group, while $B$. cylindrica represents the small, many-flowered group. The present study shows that it is true in case of B. gymnorrhiza but it is not so in B. cylindrica in which the flowers are small, but borne in three-flowered cymes. The flowers are pendulous in $B$. gymnorrhiza, while they are either horizontal or downward or slightly erect and located outward in the crown of leaves in B. cylindrica; these different orientations enable the pollinators to collect the forage comfortably. In both species, the anthesis period is the same, is confined to morning hours and quite appropriate for pollination by day-active pollinators. The field studies also indicate that their flowers receive visits exclusively from day-active pollinators. The flowers are red in B. gymnorrhiza while they are greenish-white in $B$. cylindrica. In both the species, the floral characteristics such as large or small flowers with concealed nectar, elaborate complex petal-stamen configuration, presence of basal clumps of hairs and marginal hairs suggest specialized explosive floral mechanism which is functional only when pollinating agents are involved. The same elaborate specialized mechanism is present in all other species of Bruguiera (Tomlinson et al., 1979). In B. gymnorrhiza, the petals are 14 and each petal encloses two stamens; this petal-stamen configuration requires multiple visits of pollinators for the explosion of all petals. In B. cylindrica, the flowers have only seven or eight petals with 14 or 16 stamens and closely spaced; this arrangement with reduced number of petals in relation to the small flower size is an important adaptation for the explosion of all petals of the flower and subsequent pollination in a single or two visits of the pollinator insects. Petal explosion is characteristically violent in B. gymnorrhiza, while it is non-violent in B. cylindrica. Further, similar explosive mechanism is present also in another mangrove Rhizophoraceae member, Ceriops tagal. Therefore, the floral mechanism in all the species of Bruguiera and in C. tagal is highly specialized and reflects an advanced state when compared to the simple floral mechanism that is present in Ceriops decandra, Rhizophora species and Kandelia candel - all belonging to mangrove Rhizophoraceae (Tomlinson, 1986; Juncosa and Tomlinson, 1987). Further, explosive pollination mechanism has been reported in a number of non-mangrove families such as Lamiaceae, Fabaceae, Onagraceae, Loranthaceae, Marantaceae, Urticaceae, Ericaceae, Fumariaceae, Musaceae, Cornaceae, Acanthaceae and Orchidaceae (Solomon Raju and Subba Reddi, 1995; 1996).

In Bruguiera, the explosive floral mechanism involves different functional aspects. At the time the flower opens, each petal pouch enclosing a pair of anthers includes loose pollen due to anther dehiscence during mature bud stage and stays in cocked position due to floral expansion and pressing of stamens against the interlocked margins of the petals. Marginal hairs appear to be important in holding the petals in the folded position. The petal explosion occurs due to release of tension by a slight touch at its hairy base by the probing pollinator during its vigorous search for nectar in the floral cup. During explosion, the petal unzips instantly, scattering a cloud of pollen, most or part of which falls on the pollinator. In each flower, individual petals work independently and this requires more than one visit of the same pollinator species or more than one pollinator species. This observation is substantiated by the occurrence of closed and open petals in each flower. The flowers with unexploded petals due to non-receipt of foraging visit(s) fall off without pollination or without ever-opening.

In B. gymnorrhiza, the following characters suggest adaptations for bird pollination: the flowers are recurved and typically point backwards into the crown of the tree; this facilitates an approach by a perching bird. Nectar is produced in abundance and held in the deep floral cup. The calyx is red, a colour attractive to birds. Large flowers with a heavy 
construction are suitable for a powerful pollinator like a bird (Faegri and van der Pijl, 1979). Azuma et al. (2002) examined B. gymnorrhiza flowers for scent characteristics and reported that the floral scent is lacking and the floral characteristics are indicative of bird pollination. Ghosh et al. (2008) also reported that the flowers are adapted to a range of flower visitors such as birds for pollination. Kondo et al. (1987) reported that this species is pollinated by honeyeaters, white eye and insects. Ge et al. (2003) mentioned that the flowers are pollinated by birds or butterflies. Solomon Raju (1989) reported that the flowers are exclusively pollinated by three species of passerine birds, Nectarinia asiatica, N. zeylonica and Zosterops palpebrosus at the Godavari mangrove site; then this site was ecologically healthy and there was little human interference. The present study finds that this site is now ecologically degraded and fragmented due to land use changes. With this present situation, B. gymnorrhiza is now pollinated exclusively by pollen and nectar collecting bees consisting of Apis, Nomia and Halictus genera. These bees trip the tensed petals to release the stamens which in turn eject a cloud of pollen from the already dehiscent anthers. During this process, the bees get a pollen shower all over their body, especially on their dorsal side. Further, the bees fly between individual trees in quest of more forage; this foraging activity is important to bring about cross-pollination. The production of a small number of fresh flowers daily at tree level may also compel the pollinator bees to make inter-tree flights and effect cross-pollination. Their body washings indicated that they carry pollen and transfer the same to other flowers they visit. The study suggests that B. gymnorrhiza is strictly melittophilous and this mode of pollination is as efficient as ornithophily; but the pollen feeding activity of bees may affect the pollen availability rate for the receptive stigmas at the population level which in turn may affect the natural fruit set rate. However, the bees are reliable pollinators when compared to bird pollinators. The ability of the plant to utilize birds and bees is certainly adaptive and is also essentially required for the survival, colonization and expansion of its geographical range (Tomlinson, 1986).

Tomlinson et al. (1979) stated that small-flowered Bruguiera species including $B$. cylindrica is pollinated by butterflies. These authors also mentioned the following characteristics as adaptations for butterfly pollination: small flowers in nearly erect state and displayed to the outside of the tree crown; thin branchlets which are insufficient for bird perching; greenish-yellow petals; flat calyx cup with a small quantity of nectar; and pollen release by delicate, distal stimulation of petals. In this study, the flowers have been found to have three different orientations while all other characteristics remain the same. A careful examination of these characteristics as Faegri and van der Pijl (1979) does not conform to the characteristics of butterfly-flowers. Tomlinson (1986) reported that this species is pollinated by small insects including butterflies. In this study, B. cylindrica has been found to be pollinated by bee and wasp species only. Nomia bees, Odynerus and Polistes wasps during nectar collection and the first species also during pollen collection trip all petals of a flower mostly in a single visit; then these insects get a pollen drizzle all over their body, especially on their dorsal side. Further, they fly between individual trees to collect more forage and in so doing they carry pollen on their bodies; this foraging activity is important to bring about selfand cross-pollination. Therefore, B. cylindrica is bee- and wasp-pollinated but not butterflypollinated. Tomlinson (1986) mentioned that bees and wasps represent a group of pollinators that nest in mangroves, and some populations are completely dependent on mangal for their existence. Ghosh et al. (2008) reported that some wasps and flies are highly dependent on mangroves for nesting. In the light of these reports, it is not unreasonable to suggest that bees and wasps are reliable pollinators since they nest in mangroves and collect forage from the same plants for their nutrition. 
In the present study, both the species of Bruguiera with specialized floral mechanism offer pollen and nectar as rewards to their pollinators. Pollen grains are very dry even at the time of flower-opening. Their surface sculpture is finely reticulate; they are tricolporate with numerous small and shallow depressions, and easily adhere to the body of insect pollinator so that the latter can easily transfer pollen (Kondo et al., 1987). They contain some protein content and are important in the nutrition of bee pollinators. In B. gymnorrhiza, nectar production is continuous in some flowers, while it is not so in some other flowers. Such nectar production pattern indicates that nectar secretion ceases in pollinated flowers, while its secretion is continuous until the stigma loses receptivity or until the flower is pollinated. The production of copious amount of nectar with dilute sugar concentration is the characteristic of bird-pollinated flowers (Baker and Baker, 1983). But, the nectar of B. gymnorrhiza is copious with moderate sugar concentration; it is suitable for bee pollinators as the latter tend to prefer sugar concentrations of 30 to $50 \%$ (Waller, 1972). The sugars present in the nectar include only hexoses. Roubik (1995) stated that nectar with only hexose sugars is rarely reported. Baker and Baker (1983) segregated bee flowers into those adapted to "short-tongued" bees (with less than six mm in length) and those adapted to "long-tongued" bees. These authors also reported that nectars of flowers pollinated by short-tongued bees are usually hexose-rich, while those pollinated by long-tongued bees are usually sucrose-rich. In line with this, the bees observed have tongues less than five mm length, are short-tongued and utilize the hexose nectar of B. gymnorrhiza. De Groot (1953) reported that insects in general and bees in particular require ten essential amino acids - threonine, valine, methionine, leucine, isoleucine, phenylalanine, lysine, histidine, arginine and tryptophan. The nectar of $B$. gymnorrhiza has three of these essential amino acids, lysine, histidine and arginine. The presence of these amino acids and also other non-essential amino acids, alanine, aspartic acid, glutamic acid, glycine and serine may have a role in giving the "taste" to the nectar (Baker and Baker, 1982). The nectar also has some protein content. Therefore, the nectar of $B$. gymnorrhiza with these amino acids and protein content has high nutritional value and bee pollinators are attracted to this floral source, especially during concentrated flowering period.

In $B$. cylindrica, the nectar is produced in small quantity, hexose-dominant and the sugar concentration is low. Bees and wasps utilize this nectar until exhausted. This observation is in partial agreement with the generalizations made by Baker and Baker (1982; 1983) who stated that the production of a small quantity of nectar with high sugar concentration is the characteristic of bee-flowers, and that the nectars of flowers adapted for pollination by shorttongued bees are hexose-rich, while those adapted for pollination by wasps are sucrose-rich.

Tomlinson (1986) mentioned that pollination may favour outcrossing in $B$. gymnorrhiza. Kondo et al. (1987) reported that this species produces fruit through allogamy, autogamy and geitonogamy and hence, it might be outcrossing and inbreeding. Ge et al. (2003) stated that this species has mixed mating system with outcrossing as a main system. In this study also, B. gymnorrhiza has been found to set fruit through allogamy, geitonogamy and autogamy, but all modes are functional only when petal explosion is manipulated; this suggests that pollination is essentially vector-dependent and fruit set is completely a consequence of the foraging activity of bee pollinators. The fallen flowers with some or a few unexploded petals evidenced in this study indicate that wind is not an agent of pollination. Fruit set through vector-mediated autogamy or geitonogamy indicates that $B$. gymnorrhiza is self-compatible and self-pollinating. But, protandrous condition and stigma showing receptivity commencing from day two and extending its receptivity until day four indicate that it is primarily adapted 
for cross-pollination. The small papilla and mucilage secreted by stigmatic lobes are special adaptations to retain pollen readily; these are especially important for capturing cross-pollen (Kondo et al., 1987). Therefore, B. gymnorrhiza with mixed mating system is adapted for pollination by biotic agents, the classes of which may change from time to time in the same habitat depending on the local land use changes. Similar vector-dependent mixed mating system and stigma function exists in B. cylindrica. Such a mating system facilitates fruit set in the presence of pollinators even in isolated trees of both the species of Bruguiera. With the ability to set fruit through self-pollination, these species can colonize new areas and expand their distribution range. $B$. cylindrica has scattered distribution in the study sites and also here and there it has established small patches representing pure stands. This finding is in agreement with Tomlinson (1986) who stated that it may form pure stands.

In mangrove Rhizophoraceae, the flowers have been reported to contain six or four ovules (Tomlinson, 1986). The flowers are six-ovuled in B. gymnorrhiza and four-ovuled in $B$. cylindrica; but only one ovule develops into mature seed in fertilized and fruited flowers in both the species. The production of one-seeded fruits may be due to maternal resource constraint or maternal regulation of seed set. Fruits mature within a month. The persistent and expanded calyx gives protection to the fruit; the mature fruit is well seated within the calyx and hence is not directly exposed to sunlight. Therefore, the calyx has an important role in protecting the fruit from desiccation.

In both the species of Bruguiera, the single seed formed in the fruit is not dormant and germinates immediately to produce a cylindrical hypocotyl or seedling, while still on the maternal parent. The hypocotyl emerges out of seed and fruit pericarp and remains naked until it is detached from the parent plant. This is a characteristic of "true viviparous" species (Tomlinson, 1986). While still attached to the maternal parent, the seedling develops chlorophyll and actively photosynthesizes; the parent tree supplies the water and necessary nutrients (Selvam and Karunagaran, 2004). The seedling hangs downward and detaches from the residual fruit, leaving behind its cotyledons, and falls from the maternal parent. Viviparous reproduction allows seedlings to develop some salinity tolerance before being released from the parent tree. This reproduction provides a store of nutrients before the seedlings fall off from the maternal parent and may help in quick rooting in the muddy environment. The seedling characteristics also help to develop buoyancy for dispersal and structural stability for protection against damage (Kathiresan, 2003). Therefore, vivipary is an adaptive feature to overcome the harsh tidal environment for seedling establishment.

The study shows that seedlings of Bruguiera fall off the maternal parent freely and plant themselves into the mud or stranded and planted away from parent tree. La Rue and Muzik (1954), Rabinowitz (1978) and Van Speybroeck (1992) reported similarly for this species. Kairo et al. (2001) reported that the mode of seedling dispersal depends on the forest conditions, tides, as well as the stability of the soils. Further, Van Speybroeck (1992) reported that the seedlings can plant themselves into the mud if they are dropped from maternal parent at low water or low tide. He termed it as self-planting strategy. He also reported that the seedlings float to another site to settle and develop if they fall in the water at high tide and he termed it as stranding strategy. The study shows that the seedlings of Bruguiera disperse through self-planting and stranding strategies; the former strategy is functional at low tide while the latter strategy is functional at high tide. Van Speybroeck (1992) reported that the self-planting strategy dominates in undisturbed mangrove forest whereas the stranding strategy is dominant in an exploited and open forest. The stranding strategy is especially important for regeneration and colonization of naked or semi-naked habitats and also for expanding the distribution range of the species. 
The study found that the Roseringed Parakeet feeds on the softest part of the seedlings of B. gymnorrhiza prior to their detachment from the parent tree. The seedlings attacked by this parakeet have not established new plants; their percentage however did not exceed 5\%. The feeding on these seedlings by the parakeet may be partly attributable to the scarcity of food. There is no seedling predation prior to detachment from the maternal parent in $B$. cylindrica. Sousa and Mitchell (1999) reported that after detachment from the maternal parent, seedlings experience mortality due to crab predation. Crabs prefer to feed on small propagules as the latter facilitate easy burial in burrows, have high nutritive value and low concentration of inhibiting chemicals such as tannins. Since the seedlings of both the species of Bruguiera are long, crabs may not utilize them as food source but further study is required to confirm this.

Avicennia alba, Avicennia marina and Avicennia officinalis. All the three Avicennia species studied are principally polyhaline evergreen tree species. A. alba and A. marina are small trees while $A$. officinalis is a tall tree. These tree species show flowering response to monsoon showers in June; the first monsoon showers seem to provide the necessary stimulus for flowering. Opler et al. (1976) and Ewusie (1980) have reported such a flowering response to light rains in summer season in a number of plants occurring in coastal environments. The flowering period extends until August in all the three species of Avicennia at the study sites, indicating that the flowering season is only for three months in a year. On the contrary, WiumAndersen and Christensen (1978) reported that in A. marina, flowering occurs during AprilMay. Further, Mulik and Bhosale (1989) noted that the flowering in this species is from April to September. These authors also mentioned that the flowering occurs during March-July in $A$. officinalis. The variation in the schedule and length of flowering season in these species may be a response to local environmental conditions and to avoid competition for the available pollinators depending on the flowering seasons and population size of the constituent plant species which vary with each mangrove forest. In all the three species, the flowers are borne either in terminal or axillary inflorescences. But, the average number of flowers per inflorescence varies with each species; it is the highest in A. alba, moderate in A. marina and the least in A. officinalis. This flower production rate at inflorescence level may serve as an important taxonomic characteristic for the identification of these three species.

In all, the flowers are strongly protandrous and the stamens with dehisced anthers over-arch the stigma. The stigma shows post-anthesis growth. It is erect and seated in the centre of the flower in A. alba and A. marina while it is bent and situated below the adaxial corolla lobe in $A$. officinalis. The erect stigma does not change its orientation throughout the flower life in A. alba and A. marina while the bent stigma becomes erect on day three. The stigma is bifid and appressed on the day of anthesis in all the three species; it remains in the same state also on day two in A. officinalis. The stigma commences receptivity by diverging in dorsi-ventral plane; it is receptive on day two and three in A. alba and A. marina, and on day three, four and five in $A$. officinalis. The timing of commencement of stigma receptivity in $A$. officinalis strongly contradicts with an earlier report by Subba Reddi et al. (1995) that the stigma attains receptivity three hours after anthesis with the bent stigma becoming erect. In $A$. officinalis, stigma behaviour is more advanced towards achieving cross-pollination. In all the three species, self-pollination of individual flowers is unlikely on the day of anthesis due to protandry but the stamens with dehisced anthers over-arching the stigma may facilitate the fall of pollen on the receptive stigma when the latter attains receptivity. In effect, self-pollination may occur and the same is evidenced through fruit set in bagged flowers without manual 
self-pollination. Further, the sequence and synchrony of flowering, and pollinator behaviour at tree level contribute to geitonogamy (Clarke and Meyerscough, 1991). Hand-pollination results indicate that it is self-compatible and fruit set occurs through autogamy, geitonogamy and allogamy. The hermaphroditic flowers with strong protandry and long period of flower life in these species suggest that they are primarily adapted for cross-pollination. Clarke and Meyerscough (1991) also reported that A. marina is protandrous, self-compatible and selfpollinating but the fruits resulting from spontaneous self-pollination showed a higher rate of maternal abortion reflecting an inbreeding depression. Coupland et al. (2006) reported that in A. marina, autogamy is most unlikely and emphasized the importance of pollen vectors to the reproductive success. This report is not in agreement with the results obtained in handpollination experiments on A. marina. Primack et al. (1981) suggest that protandry promotes out-crossing in mangroves, and that insect pollination facilitates it. They also suggested that geitonogamy in coastal colonizing plants would allow some fruit set in isolated colonizing plants, and thereafter the proportion of such pollinations would decline as pollen is transferred between plants. Pollen transfer between plants in such situations would still result in sibling mating. However, this is counteracted by dispersal of propagules, canopy suppression of seedlings and irregular yearly flowering among trees in close proximity. Clarke and Meyerscough (1991) reported that in A. marina, some trees flower and fruit every year while some others do not flower every year. Those with complete canopy crops did not produce another large crop the following year. A similar pattern observed within a tree where fruit is produced on one branch and in the following year heavy flowering shifts to another branch. In the present study, all the three species of Avicennia flowered annually and the flowering is uniform on all branches within a tree. The study suggests that annual mass flowering, protandry, self-compatibility and self-pollination ability are important adaptations for Avicennia species to successfully colonize new areas and expand their distribution range as pioneer mangroves.

All the three species of Avicennia are hermaphroditic and have similar floral architecture. In A. officinalis, the flowers are foetid and slightly zygomorphic while in the other two species, they are scented and actinomorphic. In all, the flowers are of open type and shallow with small aliquots of nectar which is exposed to rapid evaporation resulting in increased nectar sugar concentration. Corbet (1978) considered these characteristics as adaptations for fly pollination. Hexose-rich nectar is present in A. alba and A. marina while sucrose-rich nectar in A. officinalis. Hexose-rich nectar is the characteristic of fly- and shorttongued bee-flowers while sucrose-rich nectar is the characteristic of wasps and butterflies (Baker and Baker, 1982, 1983). The nectar sugar concentration is high and ranged from 38 to $40 \%$ in all the three Avicennia species. Cruden et al. (1983) reported that high nectar sugar concentration is the characteristic of bee-flowers while low nectar sugar concentration is the characteristic of butterfly-flowers. Baker and Baker (1982) reported that the floral nectar is an important source of amino acids for insects. Dadd (1973) stated that insects require ten essential amino acids of which arginine, lysine, threonine and histidine are present in the nectar of A. officinalis. He also reported that proline and glycine are essential amino acids for some insects; these two amino acids are also present in the nectar of A. officinalis. He further stated that other amino acids such as alanine, aspartic acid, glutamic acid, glycine and serine while not essential do increase insect growth. All these amino acids are also present in the nectar of A. officinalis. Shiraishi and Kuwabara (1970) reported that proline stimulates salt receptor cells in flies. Goldrich (1973) reported that histidine elicits a feeding response while glycine and serine invoke an extension of the proboscis. The nectars of A. alba and A. marina have not been analyzed for amino acids and hence this aspect has not been discussed. 
The flowers of all the three species of Avicennia with differences in their structural and functional characteristics as stated above have been able to attract different classes of insects bees, wasps, flies and butterflies. Of these, bees while collecting pollen and nectar while all others collecting nectar effected pollination and their ability to carry pollen has been evidenced in their body washings. Flies are known as short distance fliers and such behaviour largely results in autogamy or geitonogamy. Since these flies visit the flowers as large groups, there is automatically a competition for the available nectar which is secreted in small aliquots on the petals of all the three Avicennia species. In consequence, they shift from tree to tree in search of nectar forage and in the process they contribute to both self- and cross-pollination. All other insects are habitual long-distance fliers and affect both self- and cross-pollination. An earlier report by Subba Reddi et al. (1995) showed that only bees and flies are the pollinators of $A$. officinalis at the study sites. Tomlinson (1986) mentioned that Avicennia flowers are beepollinated. In Australia, A. marina is pollinated by ants, wasps, bugs, flies, bee-flies, cantharid beetles and moths (Clarke and Meyerscough, 1991). It is surprising to note that thrips are absent both in bud and flower stage in all the three species of Avicennia. A study on this aspect is needed to understand why thrips avoided these flowers for breeding or for forage collection.

Tomlinson (1986) documented that A. alba, A. marina and A. officinalis have very similar flowers and hence may well be served by the same class, if not by the same species of pollinators; when these species grow together, there is evidence of non-synchrony in flowering times, which might minimize the competition for pollinators (probably bees) and at the same time spread the availability of nectar over a more extended period. In the present study, these plant species grow together, flower synchronously, but served by the same classes of insects. There is no competition for pollen among different classes of insects since only bees collect pollen while all other classes of insects collect only nectar. Fly pollinators with their swarming behaviour at the flowers may enable the plant species to set fruit to the extent possible. Flies and bees are usually consistent and reliable when compared to wasps and butterflies. Therefore, the study shows flies and bees play an important role in the success of sexual reproduction in all the three species of Avicennia. Despite being pollinated by different classes of insect pollinators and having the ability to self-pollinate even in the absence of insect activity as evidenced in bagged flowers, the natural fruit set stands at $42-58 \%$ in these plant species. This low fruit set could be due to maternal abortion of self-pollinated fruits as reported by Clarke and Meyerscough (1991), non-availability of sufficient pollen to receptive stigmas due to pollen feeding activity of bees and the nutritional resource constraint to the maternal parent. Coupland et al. (2006), while reporting on fruit set aspects of A. marina in Australia mentioned that fruit set is not pollinator limited but resource limited.

In Avicenniaceae, the flowers have been reported to contain four ovules (Tomlinson, 1986). In the present study, all the three species of Avicennia are four-ovuled but only one ovule develops into mature seed in fertilized and fruited flowers as in Rhizophoraceae. The production of one-seeded fruits may be due to maternal resource constraint or maternal regulation of seed set. Fruits grow and mature within five-six weeks in A. alba and within four weeks in the other two Avicennia species. The duration of fruit maturation is not in agreement with the report of Wium-Andersen and Christensen (1978) who stated that the development from flower bud to mature fruit takes a few months. The calyx is persistent in all the three species but it does not expand to enclose the growing fruit. Therefore, the calyx has no role in sheltering or protecting the fruit. As the fruit is a leathery capsule, it does not require any protection from the calyx. 
The single seed formed in the fruit is not dormant and germinates immediately to produce chlorophyllous seedling, which remains within the fruit, while still on the maternal parent. This is a characteristic of "crypto-viviparous" species; a similar situation exists in other genera such as Aegiceras, Aegialitis, Nypa and Pelliciera (Tomlinson, 1986). In all these species, fruit is the propagule; the seedling occupies the fruit cavity. The chlorophyllous seedling actively photosynthesizes while the maternal parent supplies the water and necessary nutrients (Selvam and Karunagaran, 2004). In Avicennia species, the propagules are small, light and the entire embryo is buoyant after detachment from the maternal parent. Gradually, the fruit pericarp is lost exposing the leathery succulent cotyledons to tidal water. Rabinowitz (1978) reported that $A$. marina has an absolute requirement for a stranding period in order to establish since its propagules always float in tidal water. He also felt that the propagules must have freedom from tidal disturbance in order to take hold in the soil. In consequence, this species is restricted to the higher ground portions of the swamp where the tidal inundation is less frequent. In the present study, Avicennia species exhibit self-planting strategy at low tide and stranding strategy at high tide. However, their seedlings disperse widely in tidal water but establishment is mainly stationed in the polyhaline zone. Duke et al. (1998) reported that Avicennia seedlings disperse widely and are genetically uniform throughout their range. In the study areas, genetic studies are required to know whether all the three species studied are genetically uniform. When the seedlings settle, radicle penetrates the sediment before the cotyledons unfold. The first formal leaves appear one month after germination and the second pair one to two months (Wium-Andersen and Christensen, 1978).

Coupland et al. (2006) reported that Avicennia propagules are a rich source of nutrients and attract a diverse range of insect predators which in turn influence the rate of seedling maturation. Resource constraints and insect predation on developing fruit and seedling may both act to reduce fruit set. In A. marina and A. germinans, the seedlings tend to be high in nutritive value and have relatively few chemical defences (Smith, 1987; McKee, 1995). These species tend to exhibit a pattern of very rapid initial predation (Allen et al., 2003). In the present study, seedling predation has been evidenced in A. alba and A. marina only; in both the species, the Rose-ringed Parakeet, Psittacula krameri attacks propagules prior to their detachment from the maternal parent. Seedling predation by crabs after detachment from the maternal parent may be expected since different species of crabs have been found in the study areas. Therefore, seedling predation may reduce the success of seedling establishment in all the three species of Avicennia.

Aegiceras corniculatum. The plant is a mesohaline evergreen species. The flowering occurs during the dry season; sporadic flowering also occurs at other times of the year but it is especially significant during the rainy season. The floral characteristics such as morning anthesis, scent production, zygomorphic symmetry, short-tubed corolla with sexual organs exposed, pollen structural features and nectar production are adaptations for pollination by any class of animals (Baker and Baker, 1983; Cruden et al., 1983). Different workers reported different insects as pollinators of A. corniculatum - bees without mentioning the species by Tomlinson (1986); the bees Trigona iridipennis and Pseudapis oxybeloides at Coringa mangrove forest by Solomon Raju (1989); butterflies, bees, wasps and flies, and also birds in the Orissa mangrove forest by Pandit and Choudhury (2001). The present study shows that bees, wasps, flies and butterflies are the pollinators; Xylocopa bees are the most efficient pollinators due to their ability to collect forage quickly from each umbel and to their quick mobility between plants for want of more forage. The bees are pollen and nectar collectors while all others are nectar feeders. Pollen is a source of protein for bees and the pollen of $A$. 
corniculatum with some protein content is important for them. The small volume of nectar with high sugar concentration consisting of only two hexose sugars, fructose and glucose in $A$. corniculatum is stated to be a requirement for bees, flies and butterflies while sucrose-rich nectar is the requirement for wasps (Baker and Baker, 1983). This study shows that wasps also utilize short-tubed flowers with nectar containing only hexose sugars. Further, the nectar contains four of the ten essential amino acids required by insects (De Groot, 1953). They are arginine, lysine, threonine and histidine. It also has some non-essential amino acids. These essential and non-essential amino acids in the nectar of $A$. corniculatum serve as important nutrient source for all the insects. Near synchronous anthesis in one umbel and acropetal succession of flowers resulting in the extension of flowering period are energetically beneficial and provide forage continuously until the cessation of flowering. All the insects carry pollen and pollinate the flowers without fail. A. corniculatum with its unspecialized flowers is capable of utilizing the locally available insect species for fruit set; the insects are especially important for cross-pollination. The pollen grains being light and dry, and small in size facilitated by the medifixed versatile anthers are carried away by wind action and this wind-driven pollen movement also contributes to a small percent of fruit set. Therefore, both insects and wind are the pollinators of this plant.

In A. corniculatum, the anthers and stigma of a flower mature simultaneously; anthers dehisce an hour after anthesis while stigma remains receptive for the next two days. Pandit and Choudhury (2001) mentioned that the flowers of this plant would be able to self-pollinate with the simultaneous anther dehiscence and stigma receptivity, and with the stigma position at the level of the anthers. The plant is self-compatible and capable of autogamy, but suggested that insect pollinators are required for a higher level of fruit set. They also substantiated their suggestion by stating that pollen-ovule ratio falls within the range of facultative xenogamy according to Cruden (1977). Further, these authors observed low levels of genetic variation in this plant occurring in China; this may be an indication that fruit set in this plant is largely a function of self-pollination. Solomon Raju (1989) also reported that autogamy is a mode of self-pollination for fruit set in this plant. In the present study, hand-pollination results indicate that fruit set occurs through autogamy, wind and insects, but fruit set is highest only in the flowers pollinated by insects. All of this indicates that the plant though self-compatible and capable of setting fruit through autogamy is largely dependent on insects for maximizing fruit set rate. The pollen viability and stigma receptivity for more than three days indicate are additional adaptations to achieve cross-pollination through foraging activity of insects. In this context, Primack and Tomlinson (1980) argued that if the plant is primarily a colonizing species, it would retain the need for self-fertility if it is to establish populations in isolated localities. Therefore, A. corniculatum with self-compatible option would be able to establish populations even in isolated localities and utilize locally available flower visiting insects for both self- and cross-pollination.

In A. corniculatum, flower bud abortion is negligible and its occurrence may be due to defective origin. Numerous flattened ovules are embedded in the rounded, somewhat fleshy, and short-stalked free central placenta; it may cause an underestimation of ovule number. The present study shows that the ovules in an ovary are only thirty five but only one ovule produces seed in each fruit. Fruit maturation takes a month or slightly more than a month's time. Seed is not dormant and produces a hypocotyl within the fruit pericarp. The fruits hang downwards in this plant whereas the fruits stand upwards in Aegialitis rotundifolia. The entire fruit of A. corniculatum falls off when due for dispersal. Hypocotyls float only if they are with 
the fruit pericarp. Self-planting and stranding strategies are effective for the dispersal and establishment of hypocotyls. Therefore, the plant displays scattered occurrence and also forms pure stands in certain mesohaline areas of the mangrove forest. Bosire et al. (2005) reported higher rate of crab predation in this plant. In the present study, this aspect was not examined but the hypocotyls being small in size may contain high nutrient content and low fiber content may attract crab predators prior to their establishment.

Aegialitis rotundifolia. The genus Aegialitis represents only two shrub species, $A$. annulata and A. rotundifolia. It is recently segregated as the family Aegialitidaceae because of some distinctive features from other genera of Plumbaginaceae. Some features include anomalous secondary thickening, abundant sclereids, incipiently viviparous seeds, monomorphic pollen and homostylous flowers (Weber-El Ghobary, 1984; Tomlinson, 1986). The two species do not occur together in the same forest and have distribution in different parts of the world. A. annulata is distributed in Australia and eastern Malaysia (Tomlinson, 1986) while A. rotundifolia in South Africa and South-East Asia (Kathiresan and Bingham, 2001). A. rotundifolia has been reported to occur in Burma, Bengal and the Andamans by Tomlinson (1986). Later, Naskar and Mandal (1999) reported this species as occurring in the Sundarbans, Andaman and Nicobar islands and Mahanadi Delta of Orissa only. Ramasubramanian et al. (2003) have not mentioned about the occurrence of A. rotundifolia in their published book on the mangrove flora of Krishna and Godavari deltas of Andhra Pradesh. The present study revealed the presence of A. rotundifolia in Nachugunta Reserve Forest of Krishna Mangroves in Andhra Pradesh and hence it is the first record of A. rotundifolia from Andhra Pradesh.

Tomlinson (1986) stated the fact that Aegialitis species prefer or require exposed sites and withstand waves and tidal action. Further, he also mentioned the fact that $A$. rotundifolia does not occur within closed mangrove communities but it may occur as back mangal if soil is highly saline. Aksornkoae et al. (1992) also reported similarly about the habitat requirements of $A$. rotundifolia. At the study site also, this species occurs in seaward, euhaline and exposed sites. As the habitat of $A$. rotundifolia is highly saline, salt in high concentrations in plant tissues is toxic and hence, must be excluded by some mechanism. The absorbed salt is excreted metabolically via salt glands present on the leaf blade (Scholander, 1968). The salt evaporates or crystallizes in a conspicuous manner on the surface of leathery leaf blade of A. rotundifolia. Later, the crystallized salt blows away or washes off during cool periods by the absorption of atmospheric moisture and by rain. Therefore, A. rotundifolia with salt excretion mechanism is highly specialized to withstand high saline soils.

The plant is a dry season bloomer but it completes flowering prior to the onset of extreme dry conditions in the month of May. During this period, fluvial discharge from rivers to the sea is almost negligible and this would result in increased salinity of seawater. A steep increase in salinity levels can be expected at the site of the plant which is characteristically seaward in occurrence. Increased salinity of seawater reportedly prevents fruiting and causes senescence of immature flowers and buds (Qureshi, 1993). This may be an important factor for the plant to cease flowering by the mid-April and supply the available resources to the growing fruits to realize maximum fruit set.

A. rotundifolia species with anthesis during morning hours and odourless flowers indicates that it is adapted for pollination during daytime. The floral characteristics of this plant species such as short-tubed corolla with anthers at the flower entrance, the styles and stigmas situated slightly below the anthers, production of slightly moderate volume of nectar with high sugar concentration and the presence of only hexose sugars in nectar are adaptations for bee-pollination (Baker and Baker, 1983; Opler, 1983). Further, the nectar has the essential 
amino acids such as arginine, lysine, phenylalanine, threonine, tryptophan, valine and histidine; and also some non-essential amino acids. De Groot (1953) showed that insects in general and honeybees in particular require ten essential amino acids and seven of them are present in the nectar of this plant. The pollen also has some protein content. The flower visitors recorded are exclusively honeybees and stingless bees; the latter is also honey producers. These bees collect both pollen and nectar from the flowers. They carry pollen on their bodies and pollinate the flowers while probing for the forage. As they require more quantity of forage for honey production and brood rearing, they collect forage from as many flowers as available on A. rotundifolia and hence, contribute to both self- and cross-pollination. Naskar and Mandal (1999) mentioned that this plant is pollinated by the honey bee, Apis dorsata in the Sundarban mangroves. Bhattacharya et al. (2006) also noted that the pollen of this plant is dominant in honey collected from the Sundarbans region. Therefore, A. rotundifolia species is primarily melittophilous.

A. rotundifolia species flowers are weakly protandrous, self-compatible and selfpollinating. The protandry does not contribute to autogamy in the first two hours period of flower life as the stigmas lack receptivity during that period. Gradually, the stigmas diverge and stand away from the anthers while they attain receptivity to pollen. Individual flowers with this situation produce fruit through autogamy with the aid of wind or honeybees. The pollen grains are very large and fall down on the stigmas gravitationally due to wind action, the result of which is autogamy; if there are flowers of the same age side by side in the same or adjacent inflorescences, geitonogamy may occur. However, the flower function with reference to protandry, movement of stigmas and duration of stigma receptivity suggests that the plant is primarily evolved for outcrossing. Hand-pollination results also indicate the same and the fruit set rate is highest in open-pollinations which are largely a function of foraging activity of bees. Despite high fruit set rate in this plant, its population size is small. Pollination among the individuals of this small population may lead to a reduction in genetic diversity and molecular studies on its genetic structure would enable to know the existing level of genetic variation. Transplanting the propagules from other mangrove forests like mangrove of the Mahanadi Delta of Orissa and the Sundarbans to the study site would help to enhance gene flow in order to enable the plant to build up a stable and sustainable population size.

The flowers produce singled-ovuled ovary and the ovule invariably produces a single seed in fertilized flowers. This character is advantageous for the plant to save and use the resources for higher fruit set rate. Seed is not dormant and produces hypocotyl within the fruit pericarp while still on the parent plant; it is a characteristic of crypto-viviparous species (Carey, 1934; Das and Ghose, 2003). The fruit with hypocotyl inside grows upward like the upwardly growing naked hypocotyl of $C$. decandra. Since the hypocotyl is concealed, the entire capsule-like fruit falls off when due for dispersal. Fruit pericarp is essential for the hypocotyl to float until it is settled. Self-planting and stranding strategies are functional for the dispersal of hypocotyls. But, field studies indicate that only a few of those hypocotyls which have fallen at the parental sites settled well and showed further growth. Clarke and Kerrigan (2002) reported that the small-sized hypocotyls contain high nutrient content and low fiber content. The crabs prefer to consume such hypocotyls and feed on them prior to establishment. They also reported that $80 \%$ of the propagules failed to establish due to predation by crabs in Aegialitis annulata. In the study site of A. rotundifolia also, crabs are common and they may be consuming most of the hypocotyls prior to their establishment and hence, affecting the recruitment process of the plant. 


\section{CONCLUSIONS}

Both viviparous and crypto-viviparous species exhibit mixed mating system and adaptations for entomophily. In case of B. gymnorrhiza, the floral features suggest ornithophily but locally the plant is found to be melittophilous. The mixed mating system coupled with entomophily appears to be adaptive for the success of sexual reproduction in harsh environment which is characteristic of mangrove forest. The seed is usually the stage of the life cycle at which dispersal and the colonization of new areas occurs. It contains a reserve of food, providing the embryo with a temporary continuation of maternal support. In contrast, in both true and crypto-viviparous tree species, the seed lacks dormancy and does not perform any of these roles. The unit of dispersal in these species is not the seed but the young seedling (hypocotyl); it is naked in true viviparous species while it remained within the fruit pericarp in crypto-viviparous species suggesting that the zygote is not dependent on stored nutritional support from the endosperm or carpal tissues, but instead may be nourished directly from the maternal plant. In all the plant species, the dispersal of propagules takes place via self-planting and stranding strategies. The self-planting strategy is important in undisturbed sites while the stranding strategy is effective in exploited and open forest sites of mangroves. Therefore, the detailed information included in this paper is useful for framing effective measures for conservation and management of the studied mangrove plants as these are the characteristic species of mangrove forest. The study further provide basis for taking up extensive studies on mangrove plants for the sustainability of mangrove forest.

\section{REFERENCES}

1. Aksornkoae S., Maxwell G. S., Havanond S. and Panichsuko S., 1992 - Plants in Mangroves, Chalongrat Co., Ltd., Thailand, 120.

2. Allen J. A. and Duke N. C., 2006 - Bruguiera gymnorrhiza (large-leafed mangrove): Species Profiles for Pacific Island Agroforestry, www.traditionaltree.org

3. Allen J. A., Krauss K. W. and Hauff R. D., 2003 - Factors limiting the intertidal distribution of the mangrove species Xylocarpus granatum, Oecologia, 135, 110-121.

4. Aluri J. B., Venkata Ramana S. P. and Subba Reddi C., 2004 - Explosive pollen release, windpollination and mixed mating in the tropical tree Shorea robusta Gaertn. F. (Dipterocarpaceae), Current Science, 86, 1416-1419.

5. Aziz I. and Khan M. A., 2001 - Experimental assessment of salinity tolerance of Ceriops tagal seedlings and saplings from the Indus Delta, Pakistan, Aquatic Botany, 70, 259-268.

6. Azuma H., Toyota M., Asakawa Y., Takaso T. and Tobe H., 2002 - Floral scent chemistry of mangrove plants, Journal of Plant Research, 115, 47-53.

7. Baker H. G. and Baker I., 1973 - Some anthecological aspects of evolution of nectar-producing flowers, particularly amino acid production in nectar, in Taxonomy and Ecology, Heywood V. H. (ed.), Academic Press, London, 243-264.

8. Baker H. G. and Baker I., 1982 - Chemical constituents of nectar in relation to pollination mechanisms and phylogeny, in Biochemical aspects of evolutionary biology, Nitecki H. M. (ed.), University of Chicago Press, Chicago, 131-171.

9. Baker H. G. and Baker I., 1983 - A brief historical review of the chemistry of floral nectar, in The Biology of Nectaries, Bentley B. and Elias T. (eds), Columbia University Press, New York, 126-152.

10. Bhattacharya K., Majumdar M. R. and Bhattacharya S. G., 2006 - A Textbook of Palynology (Basic and Applied), New Central Book Agency (P) Ltd., Kolkata, 126-152.

11. Bhosale L. J. and Mulik N. G., 1991 - Proceedings of the International Seed Symposium, David N. S. and Mohammad S. (eds), Jodhpur, 201-205. 
12. Bosire J. O., Kairo J. G., Kazungu J., Koedam N. and Dahdouh Geubas F., 2005 - Predation on propagules regulates regeneration in a high-density reforested mangrove plantation, Marine Ecology Progress Series, 299, 149-155.

13. Carey G., 1934 - Further investigations on the embryology of viviparous seeds, Proceedings of Linnean Society of New South Wales, 59, 392-410.

14. Chan H. T. and Husin N., 1985 - Propagule dispersal, establishment, and survival of Rhizophora mucronata, Malaysian Forester, 48, 324-329.

15. Chiou-Rong S., Yong J. W. H. and Yang Y. P., 2005 - The Brugueira (Rhizophoraceae) species in the mangroves of Singapore, Especially on the new record and the rediscovery, Taiwania, 50, 251-260.

16. Christensen B. and Wium-Andersen S., 1977 - Seasonal growth of mangrove trees in southern Thailand, I, The phenology of Rhizophora apiculata Bl., Aquatic Botany, 3, 281-286.

17. Clarke P. J., 1993 - Dispersal of gray mangrove (Avicennia marina) propagules in southeastern Australia, Aquatic Botany, 45, 195-204.

18. Clarke P. J. and Meyerscough P. J., 1991 - Floral biology and reproductive phenology of Avicennia marina in south eastern Australia, Australian Journal of Botany, 39, 283-293.

19. Clarke P. J. and Kerrigan R. A., 2002 - The effects of seed predators on the recruitment of mangroves, The Journal of Ecology, 90, 726-736.

20. Clarke P. J., Kerrigan R. A. and Westpal C. J., 2001 - Dispersal potential and early growth in 14 tropical mangroves: do early life history traits correlate with patterns of adult distribution?, Journal of Ecology, 89, 648-659.

21. Corbet S. A., 1978 - Nectar, insect visits, and the flowers of Echium vulgare, in The Pollination of Flowers by Insects, Richards A. J. (ed.), Academic Press, London, 21-30.

22. Coupland G. T., Paling Eric I. and McGuinness Keith A., 2006 - Floral abortion and pollination in four species of tropical mangroves from northern Australia, Aquatic Botany, 84, 151-157.

23. Cruden R. W., 1977 - Pollen-ovule ratios: a conservative indicator of breeding systems in flowering plants, Evolution, 31, 32-46.

24. Cruden R. W., Hermann H. M. and Peterson S., 1983 - Patterns of nectar production and plantpollinator coevolution, in The Biology of Nectaries, Bentley B. and Elias T. (eds), Columbia University Press, New York, 80-125.

25. Dadd R. H., 1973 - Insect nutrition: current developments and metabolic implications, Annual Review of Entomology, 18, 881-420.

26. Dafni A., Kevan P. G. and Husband B. C., 2005 - Practical Pollination Biology, Enviroquest Ltd., Canada, 590.

27. Dahdouh-Guebas F., Verneirt M., Tack J. F., Van Speybroeck D. and Koedam N., 1998 Propagule predators in Kenyan mangroves and their possible effect on germination, Manual of Freshwater Research, 49, 345-350.

28. Das S. and Ghose M., 2003 - Seed structure and germination pattern of some Indian mangroves with taxonomic relevance, Taiwania, 48, 287-298.

29. Davis J. H., 1940 - The ecology and geologic role of mangroves in Florida, Papers from the Tortugas Laboratory of the Carnegie Institution of Washington, 32, 303-412.

30. De Groot A. P., 1953 - Protein and amino acid requirements of the honey bee (Apis mellifera L.), Physiologia Comparata et Oecologia, 3, 197-285.

31. Dress W. J., Newell S. J., Nastase A. J. and Ford J. C., 1997 - Analysis of amino acids in nectar from pitchers of Sarracenia purpurea (Sarraceniaceae), American Journal of Botany, 84, 1701-1706.

32. Duke N. C., John A. H. B., Goodall J. A. and Ballment E. R., 1998 - A genetic structure and evolution of species in the mangrove genus Avicennia (Avicenniaceae) in the Indo-west pacific, Evolution, 52, 1612-1626. 
33. Elmqvist T. and Cox P. A., 1996 - The evolution of vivipary in flowering plants, Oikos, 77, 3-9.

34. Ewusie J. Y., 1980 - Tropical Ecology, Heinemann Educational Books Ltd., London, 243.

35. Faegri K. and van der Pijl L., 1979 - The Principles of Pollination Ecology, Pergamon Press, New York, 243.

36. Farnsworth E. J. and Ellison A. M., 1997 - Global pattern of pre-dispersal propagule predation in mangrove forests, Biotropica, 29, 316-330.

37. Farnsworth E. J. and Farrant J. M., 1998 - Reductions in abscisic acid are linked with viviparous reproduction in mangroves, American Journal of Botany, 85, 760-769.

38. Gardener M. C. and Gillman M. P., 2002 - The taste of nectar - a neglected area of pollination ecology, Oikos, 98, 552-557.

39. Ge J., Cai B. and Lin P., 2003 - Mating system and outcrossing rates of four Bruguiera gymnorrhiza populations of mangrove in China, Nature and Science, 1, 42-48.

40. Ghosh A., Gupta S., Maity S. and Das S., 2008 - Study of floral morphology of some Indian mangroves in relation to pollination, Research Journal of Botany, 3, 9-16.

41. Goebel K. E., 1905 - Organography of Plants, Hafner, New York.

42. Goldrich N. R., 1973 - Behavioural responses of Pharmia regina (Meigen) to labellar stimulation with amino acids, Journal of General Physiology, 61, 74-88.

43. Harborne J. B., 1973 - Phytochemical Methods. Chapman and Hall, London.

44. Juncosa A. M. and Tomlinson P. B., 1987 - Floral development in mangrove Rhizophoraceae, American Journal of Botany, 74, 1263-1279.

45. Kairo J. G., Dahdouh-Guebas F., Bosire J. and Koedam N., 2001 - Restoration and management of mangrove systems - a lesson for and from the East African regions, South African Journal of Botany, 67, 383-389.

46. Kathiresan K., 2003 - Biology of Mangroves in Biodiversity in Mangrove Ecosystems, Kathiresan K. and Subramanian A. N. (ed.), UNU-UNESCO International Training Course Manual, Annamalai University, Parangipettai, 74-90.

47. Kathiresan K. and Bingham B. L., 2001 - Biology of mangroves and mangrove ecosystems, Advances in Marine Biology, 40, 81-251.

48. Kathiresan K. and Rajendran N., 2003 - Mangroves, in UNU-UNESCO International Training Course on Biodiversity in Mangrove Ecosystems, Course Manual Kathiresan K. and Subramanian A. N., (eds), Annamalai University, 138-147.

49. Kondo K., Nakamurat T., Tsuruda K., Saito N. and Yaguchi Y., 1987 - Pollination in Bruguiera gymnorrhiza and Rhizophora mucronata (Rhizophoraceae) in Ishigaki Island, The Ryukyu Islands, Japan, Biotropica, 19, 377-380.

50. Kress W. J., 1974 - The floral biology of Rhizophora mangle in south Florida, Undergraduate Honors Thesis. Biology Department, Harvard University.

51. LaRue C. D. and Muzik T. J., 1954 - Does mangrove really plant its seedling?, Nature, 114, 661-662.

52. MacNae W., 1968 - A general account of the flora and fauna of mangrove swamps and forests in the Indo-West pacific regions, Advances in Marine Biology, 6, 73-270.

53. McGuinness K. A., 1997 - Dispersal, establishment and survival of Ceriops tagal propagules in the north Australian mangrove forest, Oecologia, 109, 80-87.

54. McKee K. L., 1995 - Mangrove species distribution and propagule predation in Belize: An exception to the dominance-predation hypothesis, Biotropica, 27, 334-345.

55. Meeuse B. and Morris S., 1984 - The Sex Life of Flowers, Facts on File, New York, 152.

56. Mitchell R. J., Karron J. D., Holmquist K. G. and Bell J. M., 2004 - The influence of Mimulus ringens floral display size on pollinator visitation patterns, Functional Ecology, 18, 116-124.

57. Mulik N. G. and Bhosale L. J., 1989 - Flowering phenology of the mangroves from the west coast of Maharashtra, Journal of Bombay Natural History Society, 86, 355-359.

58. Muniyandi K., 1986 - Studies on mangroves of Pitchavaram (South East Coast of India), Ph.D. Thesis, Annamalai University, Parangipettai, India. 
59. Naskar K. and Mandal R., 1999 - Ecology and biodiversity of Indian Mangroves Part - I Global Status, Daya Publishing House, New Delhi, 361.

60. Opler P. A., 1983 - Nectar production in a tropical ecosystem, in Bentley B. and Elias T. (eds), The Biology of Nectaries, Columbia University Press, New York, 30-79.

61. Opler P. A., Frankie G. W. and Baker H. G., 1976 - Rainfall as a factor in the release, timing and synchronization of anthesis by tropical trees and shrubs, Journal of Biogeography, 3, 231236.

62. Pandit S. and Choudhury B. C., 2001 - Factors effecting pollinator visitation and reproductive success in Sonneratia caseolaris and Aegiceras corniculatum in the mangrove forest in India, Journal of Tropical Ecology, 17, 431-447.

63. Pannier F. and Pannier R. F., 1975 - Physiology of vivipary in Rhizophora mangle L. Proceedings of International Symposium on Biology and Management of Mangroves, 2, 632639.

64. Primack R. B. and Tomlinson P. B., 1980 - Variation in tropical forest breeding systems, Biotropica, 12, 229-231.

65. Primack R. B., Duke N. C. and Tomlinson P. B., 1981 - Floral morphology in relation to pollination ecology in five Queensland coastal plants, Austrobaileya, 4, 346-355.

66. Qureshi M. T., 1993 - Rehabilitation and management of mangrove forests of Pakistan, in Towards the Rational Use of High Salinity Tolerant Plants, 1, Leith H. and Al Masoom A., (eds), Kluwer Academic Publishers, The Netherlands, 89-95.

67. Rabinowitz D., 1978 - Mortality and initial propagules size in mangrove seedlings in Panama, Journal of Ecology, 66, 45-51.

68. Ramasubramanian R., Ravishankar T. and Sridhar D., 2003 - Mangroves of Andhra Pradesh, Identification and Conservation Manual, M. S. Swaminathan Research Foundation, Chennai.

69. Roubik D. W., 1995 - Pollination of Cultivated Plants in the Tropics, FAO Agricultural Services Bulletin, 118.

70. Scholander P. F., 1968 - How mangroves desalinate water, Physiologia Plantarum, 21, 251261.

71. Selvam V. and Karunagaran V. M., 2004 - Coastal Wetlands: Mangrove Conservation and Management. Orientation Guide 1. Ecology and Biology of Mangroves, M. S. Swaminathan Research Foundation, Chennai.

72. Shiraishi A. and Kuwabara M., 1970 - The effects of amino acids on the labellar hair chemosensory cells of the fly, Journal of General Physiology, 56, 768-782.

73. Slansky F. and Feeny P., 1977 - Stabilization of the rate of nitrogen accumulation by larvae of the cabbage butterfly on wild and cultivated food plants, Ecological Monographs, 47, 209-228.

74. Smith T. J., 1987 - Seed predation in relation to tree dominance and distribution in mangrove forests, Ecology, 68, 266-273.

75. Solomon Raju A. J., 1989 - Reproductive ecology of Ocimum americanum L. and O. basilicum L. (Lamiaceae) in India, Plant Species Biology, 4, 107-116.

76. Solomon Raju A. J. and Subba Reddi C., 1995 - Explosive pollen release and pollination in flowering plants, Proceedings of Indian National Science Academy, B61, 323-332.

77. Solomon Raju A. J. and Subba Reddi C., 1996 - The explosive floral-mechanism and pollination in the genus Hyptis (Lamiaceae), Proceedings of Indian National Science Academy, B62, 117-124.

78. Solomon Raju A. J. and Jonathan K. H., 2008 - Reproductive ecology of mangrove trees Ceriops decandra (Griff.) Ding Hou and Ceriops tagal (Perr.) C. B. Robinson (Rhizophoraceae), Acta Botanica Croatica, 67, 201-208.

79. Solomon Raju A. J., Jonathan K. H. and Lakshmi A. V., 2006 - Pollination biology of Ceriops decandra (Griff.) Ding Hou (Rhizophoraceae), an important true viviparous mangrove tree species, Current Science, 91, 1235-1238. 
80. Sousa W. P. and Mitchell B. J., 1999 - The effect of seed predators on plant distributions: is there a general pattern in mangroves?, Oikos, 86, 55-66.

81. Subba Reddi C. and Solomon Raju A. J., 1997 - Reproductive biology of three mangrove plant species, Indian Journal of Forestry, 20, 153-157.

82. Subba Reddi C., Solomon Raju A. J. and Reddy S. N., 1995 - Pollination ecology of Avicennia officinalis L. (Avicenniaceae), Journal of Palynology, 31, 253-260.

83. Sun M., Wong K. C. and Lee J. S. Y., 1998 - Reproductive biology and population genetic structure of Kandelia candel (Rhizophoraceae), a viviparous mangrove species, American Journal of Botany, 85, 1631-1637.

84. Thawley A. R., 1969 - The components of honey and their effects on its properties: A review, Bee World, 50, 51-60.

85. Tomlinson P. B., 1986 - The Botany of Mangroves, Cambridge University Press, New York.

86. Tomlinson P. B., Primack R. B. and Bunt J. S., 1979 - Preliminary observations on floral biology in mangrove Rhizophoraceae, Biotropica, 11, 256-277.

87. Van Speybroeck D., 1992 - Regeneration strategy of mangrove along the Kenyan coast, Hydrobiologia, 247, 243-251.

88. Waller G. D., 1972 - Evaluating responses of honeybees to sugar solution using an artificial flower feeder, Annals of Entomological Society of America, 6, 857-862.

89. Weber-El Ghobary M. O., 1984 - The systematic relationships of Aegialitis (Plumbaginaceae) as revealed by pollen morphology, Plant Systematics and Evolution, 144, 53-58.

90. Wium Andersen S. and Christensen B., 1978 - Seasonal growth of mangrove trees in southern Thailand, II, Phenology of Bruguiera cylindrica, Ceriops tagal, Lumnitzera littorea and Avicennia marina, Aquatic Botany, 5, 383-390.

91. Yao Y., Bera S., Wand Y. and Li C. S., 2006 - Nectar and pollen sources for honeybee (Apis cerana cerana Fabr.) in Qingian Mangrove Area, Hainan Island China, Journal of Integrative Plant Biology, 48, 1266-1273. 